\title{
Estimating criteria pollutant emissions using the California Regional Multisector Air Quality Emissions (CA-REMARQUE) model v1.0
}

\author{
Christina B. Zapata ${ }^{1}$, Chris Yang ${ }^{2}$, Sonia Yeh ${ }^{2}$, Joan Ogden ${ }^{2}$, and Michael J. Kleeman ${ }^{1}$ \\ ${ }^{1}$ Department of Civil and Environmental Engineering, University of California - Davis, Davis, California, USA \\ ${ }^{2}$ Institute of Transportation Studies, University of California - Davis, Davis, California, USA
}

Correspondence: Michael J. Kleeman (mjkleeman@ucdavis.edu)

Received: 16 July 2017 - Discussion started: 8 August 2017

Revised: 24 January 2018 - Accepted: 26 January 2018 - Published: 11 April 2018

\begin{abstract}
The California Regional Multisector Air Quality Emissions (CA-REMARQUE) model is developed to predict changes to criteria pollutant emissions inventories in California in response to sophisticated emissions control programs implemented to achieve deep greenhouse gas (GHG) emissions reductions. Two scenarios for the year 2050 act as the starting point for calculations: a business-as-usual (BAU) scenario and an $80 \%$ GHG reduction (GHG-Step) scenario. Each of these scenarios was developed with an energy economic model to optimize costs across the entire California economy and so they include changes in activity, fuels, and technology across economic sectors. Separate algorithms are developed to estimate emissions of criteria pollutants (or their precursors) that are consistent with the future GHG scenarios for the following economic sectors: (i) on-road, (ii) rail and off-road, (iii) marine and aviation, (iv) residential and commercial, (v) electricity generation, and (vi) biorefineries. Properly accounting for new technologies involving electrification, biofuels, and hydrogen plays a central role in these calculations. Critically, criteria pollutant emissions do not decrease uniformly across all sectors of the economy. Emissions of certain criteria pollutants (or their precursors) increase in some sectors as part of the overall optimization within each of the scenarios. This produces nonuniform changes to criteria pollutant emissions in close proximity to heavily populated regions when viewed at $4 \mathrm{~km}$ spatial resolution with implications for exposure to air pollution for those populations. As a further complication, changing fuels and technology also modify the composition of reactive organic gas emissions and the size and composition of particulate matter emissions. This is most notably apparent through a comparison of emissions reductions for different
\end{abstract}

size fractions of primary particulate matter. Primary $\mathrm{PM}_{2.5}$ emissions decrease by $4 \%$ in the GHG-Step scenario vs. the BAU scenario while corresponding primary $\mathrm{PM}_{0.1}$ emissions decrease by $36 \%$. Ultrafine particles $\left(\mathrm{PM}_{0.1}\right)$ are an emerging pollutant of concern expected to impact public health in future scenarios. The complexity of this situation illustrates the need for realistic treatment of criteria pollutant emissions inventories linked to GHG emissions policies designed for fully developed countries and states with strict existing environmental regulations.

\section{Introduction}

Many countries around the world are debating cost-effective candidate strategies to mitigate threats to long-term prosperity including climate change and threats to public health. These specific issues are at least partially linked through regional air quality. Realistic mitigation plans for greenhouse gas (GHG) emissions $\left(\mathrm{CO}_{2}, \mathrm{CH}_{4}, \mathrm{~N}_{2} \mathrm{O}\right.$, etc.) usually include measures encouraging reduced energy consumption or changes to energy sources leading to reduced GHG emissions. These measures also impact emissions of criteria pollutants or their precursors (particulate matter $(\mathrm{PM}), \mathrm{NO}_{x}$, $\mathrm{SO}_{x}$, volatile organic compounds (VOCs), $\mathrm{NH}_{3}$, etc.) that influence regional air quality. Air quality influences public health through impacts on mortality (primarily related to $\mathrm{PM}_{2.5}$ ) and morbidity (primarily related to $\mathrm{PM}_{2.5}$ and $\mathrm{O}_{3}$ ).

Many previous attempts to characterize the impact of climate policies on criteria pollutant emissions, air quality, and public health have often emphasized countries where potential health savings are largest. These previous studies have 
also usually performed calculations for large geographic areas without resolving details at regional scales appropriate for California (Bollen et al., 2009; Garcia-Menendez et al., 2015; Rafaj et al., 2012; Shindell et al., 2012; van Aardenne et al., 2010; West et al., 2013). These studies represent California with only a small number of grid cells or they use simplistic representations of California's energy economy.

More recent studies addressing interactions between climate policies, emissions, and air quality in the US (Keshavarzmohammadian et al., 2017; Loughlin et al., 2011; Ran et al., 2015; Rudokas et al., 2015; Trail et al., 2015; Zhang et al., 2016) have allocated future emissions using enhanced population surrogates (Ran et al., 2015) and federal climate policies (Trail et al., 2015). The current study builds on this previous work to explicitly account for California's ambitious climate regulations broken down into detailed sectors including realistic siting of biofuel facilities. The current study also considers the effects of regenerative braking and exhaust particulate size and speciation changes from the heavy use of alternative and renewable fuels across multiple economic sectors. These enhancements support the desired level of detailed analysis for the intersection of air, climate, and energy choices in California.

The purpose of this paper is to describe the California Regional Multisector Air Quality Emissions (CAREMARQUE) model that can translate complex GHG mitigation scenarios into criteria pollutant emissions inventories with sufficient detail to support fine-scale air quality models and public health analysis. Here we emphasize solutions that optimize statewide total GHG emissions across the entire California economy, with potential trade-offs between different source types to achieve this objective. The complex optimization problem requires an energy economic model and so we focus on scenarios predicted by the CA-TIMES energy economic model as the starting point for the analysis. The detailed algorithms within the CA-REMARQUE model are then developed to translate predicted changes in GHG emissions associated with source activity, fuels, and technology into criteria pollutant emissions that are spatially resolved $(4 \mathrm{~km})$ for each sector of the California economy. Changing emissions profiles caused by fuel substitutions are also accounted for. Final results are compared to an expert-analysis method developed for a previous global analysis to illustrate why the complex methods described in this study are needed when analyzing developed regions like California that have major diversified economies and a long history of environmental regulations.

\section{Methodology}

Energy scenarios are translated to criteria pollutant emissions inventories by the CA-REMARQUE model in a multistep process with unique algorithms developed for each major sector of the economy that emits air pollution precursors. All calculations start with energy scenarios developed by the energy economic model CA-TIMES. The details needed to produce criteria pollutant emissions inventories are discussed in the following sections.

\subsection{CA-TIMES energy model and energy scenarios}

CA-TIMES (McCollum et al., 2012; Yang et al., 2014, 2015) is a bottom-up energy-economic model originally based on the TIMES (The Integrated MARKAL-EFOM System) model (Loulou et al., 2016). CA-TIMES is a costminimization optimization model that balances energy supply and demand system-wide from all energy sectors of the economy. Demand includes the transportation, industrial, residential, commercial, and agricultural sectors. Fuel and electricity supply includes electric, biofuel, hydrogen production plants, and biofuel and petroleum refineries. Demand was assumed fixed for the scenarios considered (Yang et al., 2014, 2015). CA-TIMES allows imports from out of state, such as oil, natural gas, and electricity. Renewables and biomass are handled separately and modeled explicitly as located in or out of state and imports are determined on a cost basis. CA-TIMES contains capital and operation costs for each technology and diverse fuel and energy carriers, and it calculates GHG emissions for $\mathrm{CO}_{2}, \mathrm{CH}_{4}$, and $\mathrm{N}_{2} \mathrm{O}$.

The case studies considered in the present study focus on two CA-TIMES scenarios in 2050: (i) a business-as-usual (BAU) scenario that achieves the goals outlined in California Assembly Bill 32 (AB32), the Global Warming Solutions Act of 2006 and (ii) a climate-friendly GHG-Step scenario that achieves an $80 \%$ reduction (relative to 1990 level) in GHG emissions by 2050. Statewide GHG emissions under each scenario are summarized in Fig. 1. In the GHGStep scenario a "step" GHG emissions constraint in which a constant 2020 cap is held until 2050 is applied, and then an $80 \%$ reduction is applied from 2050 onward. This allows the model freedom to adopt strategies that lower GHG emissions prior to 2049 if those strategies minimize costs. This 2050 GHG constraint causes aggressive change over the period 2040-2049 but does not shock to the energy system in 2050 because the CA-TIMES model has perfect foresight and optimally minimizes the energy system cost (with a $4 \%$ discount factor) over the entire period from 2010 to 2050, making investment decisions to meet targets. Also, CA-TIMES investments in low-GHG technologies start slowly and grow to reach the required market share to meet the targets since technologies have finite lifetimes and cannot take over respective markets instantaneously. The criteria pollutant emissions between 2010 and 2049 were not analyzed in the current study but a summary of CA-TIMES results for intermediate years is provided by Yang et al. (2015). Both BAU and GHG-Step scenarios include current and sunset GHG regulations in California: Corporate Average Fuel Economy (CAFE) standards (California Air Resources Board, 2005, 2009b, 2010b), the Zero Emission Vehicle (ZEV) mandate 


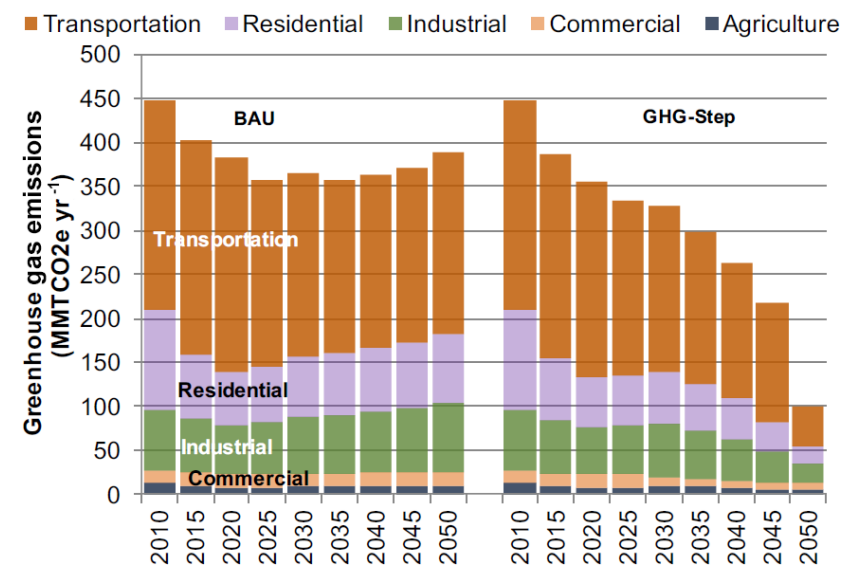

Figure 1. Greenhouse gas emissions in California under the BAU and GHG-Step scenarios.

(California Air Resources Board, 2012b, c, d, e, f), Low Carbon Fuel Standard (LCFS) (California Air Resources Board, 2009c, 2011c), Cap-and-Trade Program (California Air Resources Board, 2011d, 2017), and federal and state incentives (tax credits and subsidies). CA-TIMES predicts total annual energy consumption in California for the year 2050 to be $8763 \mathrm{PJ}$ in the BAU scenario and $7679 \mathrm{PJ}$ in the GHG-Step scenario (reference value for 2010 is approximately $7500 \mathrm{PJ}$ ) (Yang et al., 2015).

The methods to estimate criteria emissions for different sources developed in the current paper take advantage of the best available information describing future energy and emissions as a function of location. The quality of this information varied considerably for each major source category and so the details of the methodology also varied. Figure 2 illustrates an overview of the general procedure. The changes in energy consumption and GHG emissions produced by CATIMES for each energy sector in the year 2050 were translated into changes in criteria pollutant emissions by accounting for changing energy activity levels or fuel switching. Literature searches were conducted to identify any previous studies describing spatial locations of future emissions within California. Altered emissions for the year 2050 were then projected from a 2010 emissions inventory with $4 \mathrm{~km}$ spatial resolution provided by the California Air Resources Board (CARB). Additional details for each major source type are discussed below.

\subsection{CA-REMARQUE on-road mobile algorithms}

On-road mobile sources include passenger cars, light-duty trucks (LDTs), medium-duty trucks (MDTs), heavy-duty trucks (HDTs), buses, motorcycles, and motor homes. Onroad emissions were generated in a multistep process summarized in Fig. 3. In the first step, 2010-2035 emissions projection trends from the Emission Factor (EMFAC) 2011 model (California Air Resources Board, 2011a) were used to extrapolate further to 2050. In the second step, an intermediate $4 \mathrm{~km}$ vehicular emissions inventory was generated by combining EMFAC 2050 projections with a $20104 \mathrm{~km}$ emissions inventory as a spatial surrogate. In the third step, the 2050 fossil fuel vehicular emissions rates that were projected from EMFAC as well as new emissions rates gathered from alternative fuel emissions literature were used to scale the $4 \mathrm{~km}$ intermediate mobile emissions inventory based on the vehicle miles traveled (VMTs), trips, and vehicle class and (conventional and alternative) fuel consumption output produced for each CA-TIMES scenario.

\subsubsection{EMFAC emissions and activity projections}

Criteria pollutant emissions for on-road mobile sources in future years were forecast using the EMFAC 2011 model developed by the California Air Resources Board (CARB) (California Air Resources Board, 2011a). EMFAC 2011 accounts for annual VMT trends and vehicle fleet composition turnover using Department of Motor Vehicles (DMV) data. EMFAC incorporates the latest on-road mobile policies including the Low-Emission Vehicle emissions standards, LCFS, Pavley Clean Car Standard, and the Truck and Bus ruling (California Air Resources Board, 2011a). EMFAC 2011 predicts past, present, and future year (up to 2035 or 2040) emissions including anticipated future emissions standards and regulations specific to California. EMFAC predicts emissions and energy activity (VMT, trips, vehicles, gallons of fuel) for 69 geographical area indexes (GAIs) which represent the intersection of air basins and counties (listed in Table S1 in the Supplement).

In the current study, EMFAC was run for each calendar year from 2020 to 2035 to infer the emissions trends that could then be extrapolated to 2050. A simple linear regression model was used to represent VMT over the period 20202035, while a logarithmic regression model was fit to pollutant emissions for each vehicle type over the same time period. Future studies will use EMFAC 2014, which directly predicts emissions in 2050, making this step unnecessary.

\subsubsection{Spatial allocation of mobile source emissions in an intermediate 2050 inventory}

An existing on-road mobile emissions inventory for the year 2010 with $4 \mathrm{~km}$ spatial resolution served as the starting point for the projection of an intermediate emissions inventory in 2050. Scaling factors to account for VMT growth and adoption of existing policies were first calculated as the ratios between EMFAC emissions from 2010 and (extrapolated) 2050 within each of the 69 GAI regions. Separate scaling factors were developed for each pollutant emitted from different vehicle classes and control technologies as represented by unique emissions inventory codes (EICs). The combined intermediate emissions (em) scaling factor $\mathrm{SF}_{\mathrm{act}}+$ met defined in Eq. (3) reflects independent changes in activity (act) 


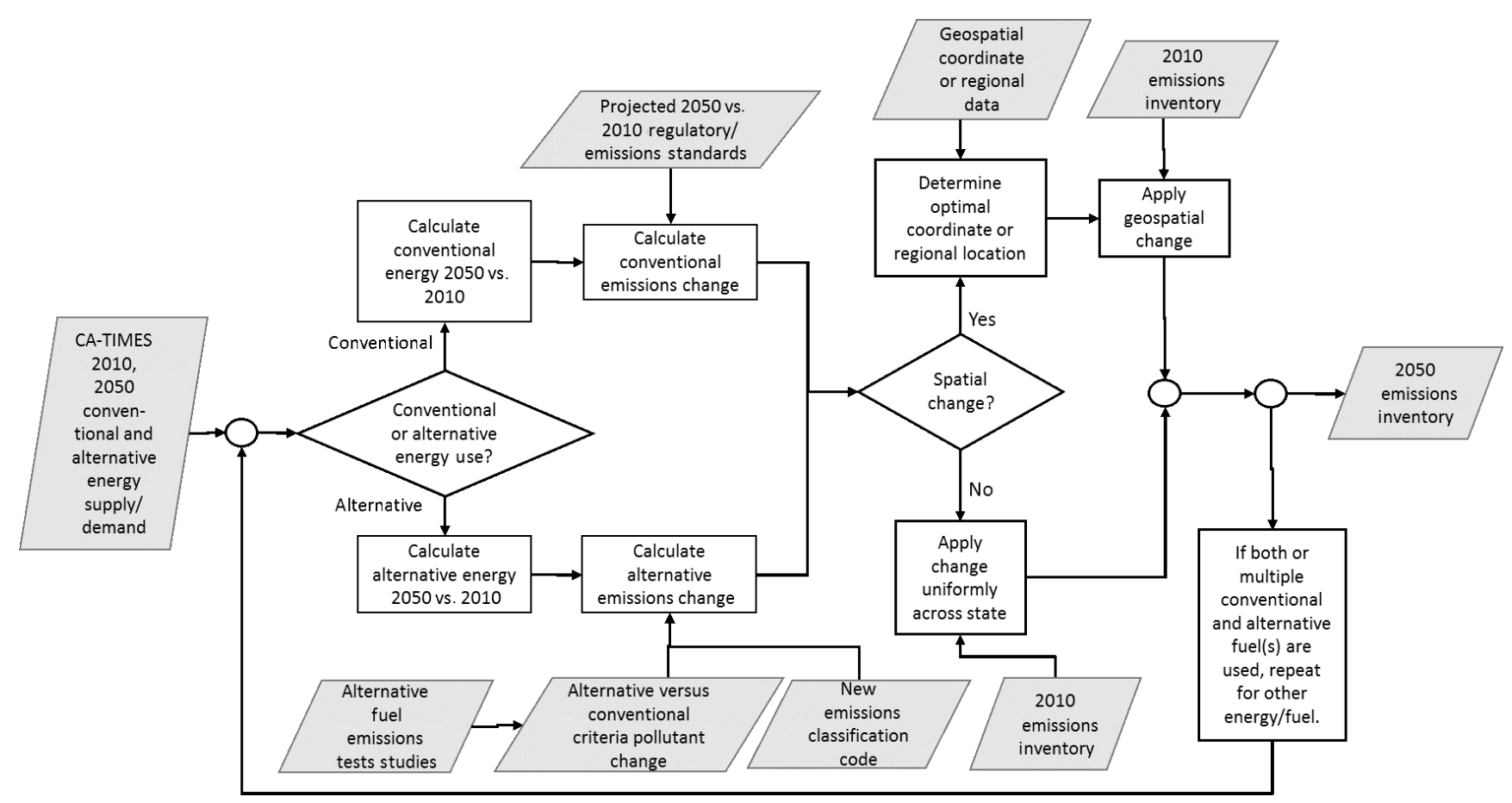

Figure 2. Process diagram of emissions inventory generation for each sector or mode.

(Eq. 1) and meteorology (met) (Eq. 2). Future 2054 temperature and relative humidity generated at $4 \mathrm{~km}$ resolution with WRF3.2 (Zhang et al., 2014) were averaged to GAI regions used by EMFAC to produce hour-specific reactive organic gas (ROG) emissions rates that vary from the annual average emissions rates. Activity is either defined as VMTs or vehicle trips, depending on the emissions process. For example, activity equals VMT for tailpipe emissions rates (e.g., g NO mile ${ }^{-1}$ ) or tire- and brake-wear emissions $\left(\mathrm{g} \mathrm{PM} \mathrm{mile}^{-1}\right)$. Otherwise, activity equals the number of vehicles within each type, fuel, and aftertreatment category such as for evaporative emissions of non-methane hydrocarbons ( $\mathrm{g}$ NMHC vehicle ${ }^{-1}$ ) from the fuel system (nontailpipe emissions). Emissions rates are highly dependent on the emissions process (evaporative, exhaust, tire or brake wear), fuel (gasoline or diesel), and the aftertreatment device (catalytic or non-catalytic).

Emissions within each $4 \mathrm{~km}$ grid cell of the 2010 inventory are multiplied by the 2050 to 2010 scaling factor $\mathrm{SF}_{\text {act }+ \text { met }}$ to estimate the "intermediate" 2050 emissions that will be further modified according to various additional policy choices represented in CA-TIMES.

$$
\begin{aligned}
& \mathrm{SF}_{\mathrm{act}}=\frac{\mathrm{em}\left(\mathrm{act}_{2050}, \mathrm{met}_{2010}\right)}{\mathrm{em}\left(\mathrm{act}_{2010}, \text { met }_{2010}\right)} \\
& \mathrm{SF}_{\text {met }}=\frac{\mathrm{em}\left(\operatorname{act}_{2010}, \text { met }_{2050}\right)}{\operatorname{em}\left(\operatorname{act}_{2010}, \operatorname{met}_{2010}\right)} \\
& \mathrm{SF}_{\mathrm{act}+\mathrm{met}}=\mathrm{SF}_{\mathrm{act}} \cdot \mathrm{SF}_{\mathrm{met}}
\end{aligned}
$$

\subsubsection{CA-TIMES modification of intermediate 2050 on-road mobile emissions}

Statewide CA-TIMES scaling factors were applied to the 2050 intermediate emissions inventory described in the previous section uniformly at all locations to produce the final 2050 emissions inventory. EMFAC accounts for population growth and emissions changes that are required by existing air quality rules and regulations through 2050. CATIMES accounts for additional changes that will be required to comply with state GHG targets but which have not yet been placed into emissions rules and regulations. The final inventory retains the spatial and temporal features inherent in the intermediate emissions inventory but incorporates updated information about new fuels, technologies, and emissions rates based on statewide predictions from CA-TIMES (Fig. 4).

EMFAC vehicle classes expressed as EIC codes were mapped to compatible vehicle classes used by CA-TIMES as described in Table S2 in the Supplement. Spark ignition (gasoline) vehicles in CA-TIMES were further classified as catalyst equipped or non-catalyst equipped to match EMFAC categories. EMFAC resolves non-catalystequipped and catalyst-equipped gasoline vehicles into several sub-categories (light-heavy-duty truck and heavy-heavyduty truck; see Table S2 in the Supplement for complete description of vehicle classes) while CA-TIMES does not include this level of resolution. 


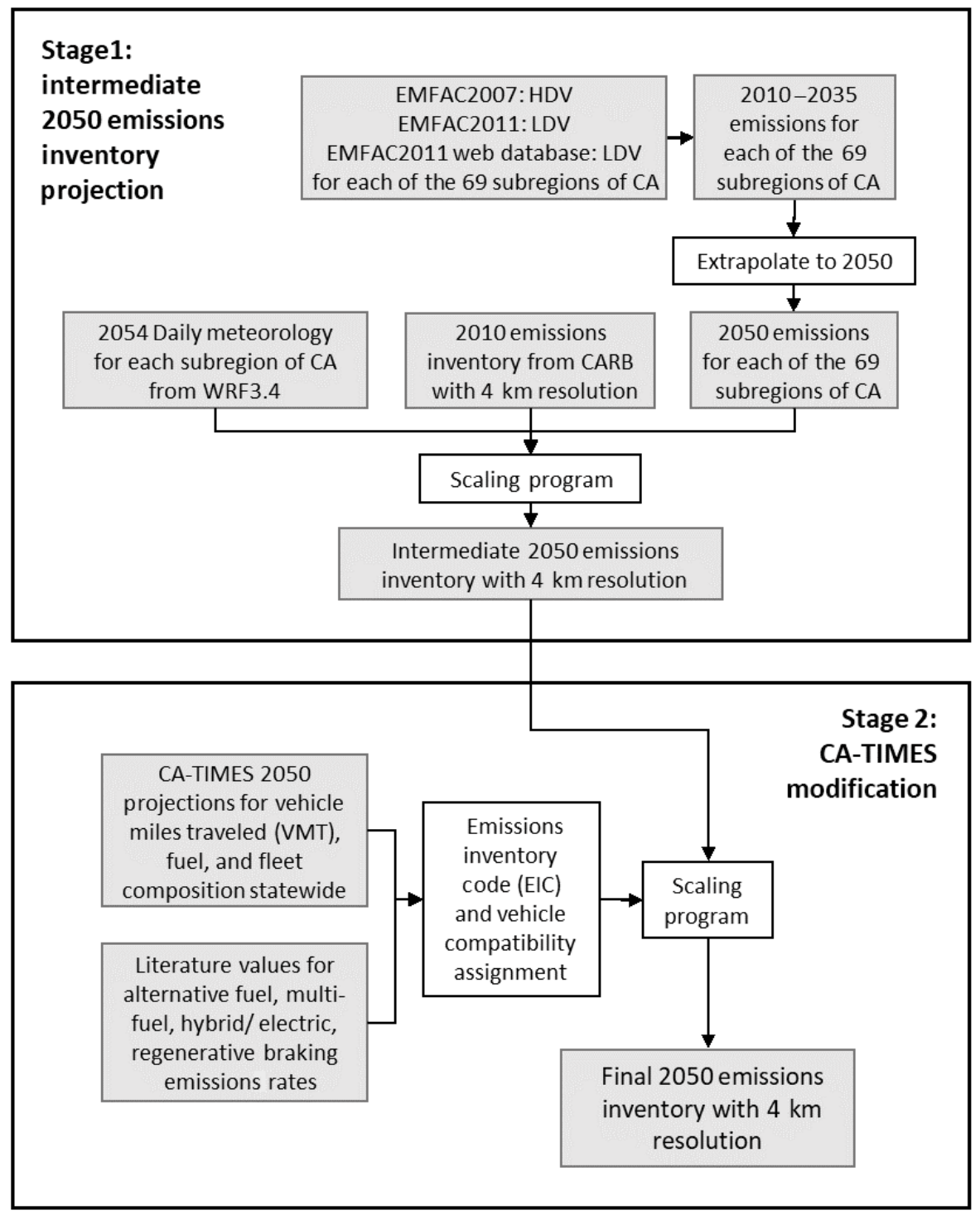

Figure 3. Simplified sequence of algorithms, calculations, and inputs used in developing the CA-TIMES alternative fuel on-road mobile emissions inventory per scenario. EIC is emissions inventory code.

The use of new fuels in the on-road fleet required special consideration during preparation of the 2050 emissions inventory. As a starting point, emissions rates from EICs representing conventionally fueled vehicles were calculated from 2050 EMFAC output by dividing each pollutant emissions by the respective vehicle activity indicator (either VMT, vehicle number, or fuel consumption) to serve as a baseline for CA-TIMES scenario adjustments. Next, the 181 combinations of alternative fuels and electric hybrid, dedicated or single/multi-fueled applications, and vehicle weight classes were mapped to EMFAC by vehicle class and reference fuel (see Tables S2 and S3 in the Supplement). CA-TIMES predicts the amount of alternative fuel consumed, not the VMT associated with that alternative fuel. The VMT associated with each alternative fuel was therefore estimated as the
VMT associated with the conventional fuel divided by the energy content of the consumed conventional fuel $\left(E_{\mathrm{V}}\right)$ multiplied by the energy content of the alternative fuel $\left(E_{\mathrm{v}, \mathrm{f}}\right)$ output by CA-TIMES. This calculation assumes that vehicle weight and aerodynamics do not change significantly as alternative fuels are adopted. Finally, the emissions rate for each alternative fuel was estimated based on a literature review of emissions factors for conventionally vs. alternatively fueled vehicles. Reference emissions rates $\left(\mathrm{er}_{\mathrm{v}}\right.$, ref $)$ and alternative to conventional scaling factors $\left(\mathrm{er}_{\mathrm{v}, \mathrm{f}} / \mathrm{er}_{\mathrm{v}, \text { ref }}\right)$ for the vehicle fuels of interest are listed in Table 1.

Equation (4) illustrates how the total emissions $\left(\mathrm{em}_{\mathrm{v}}\right)$ were calculated for a given vehicle class (subscript $v$ ) by summing the product of the emissions rate and VMT for each fuel (subscript $f$ ) for the number of different fuels $(n)$ consumed by 


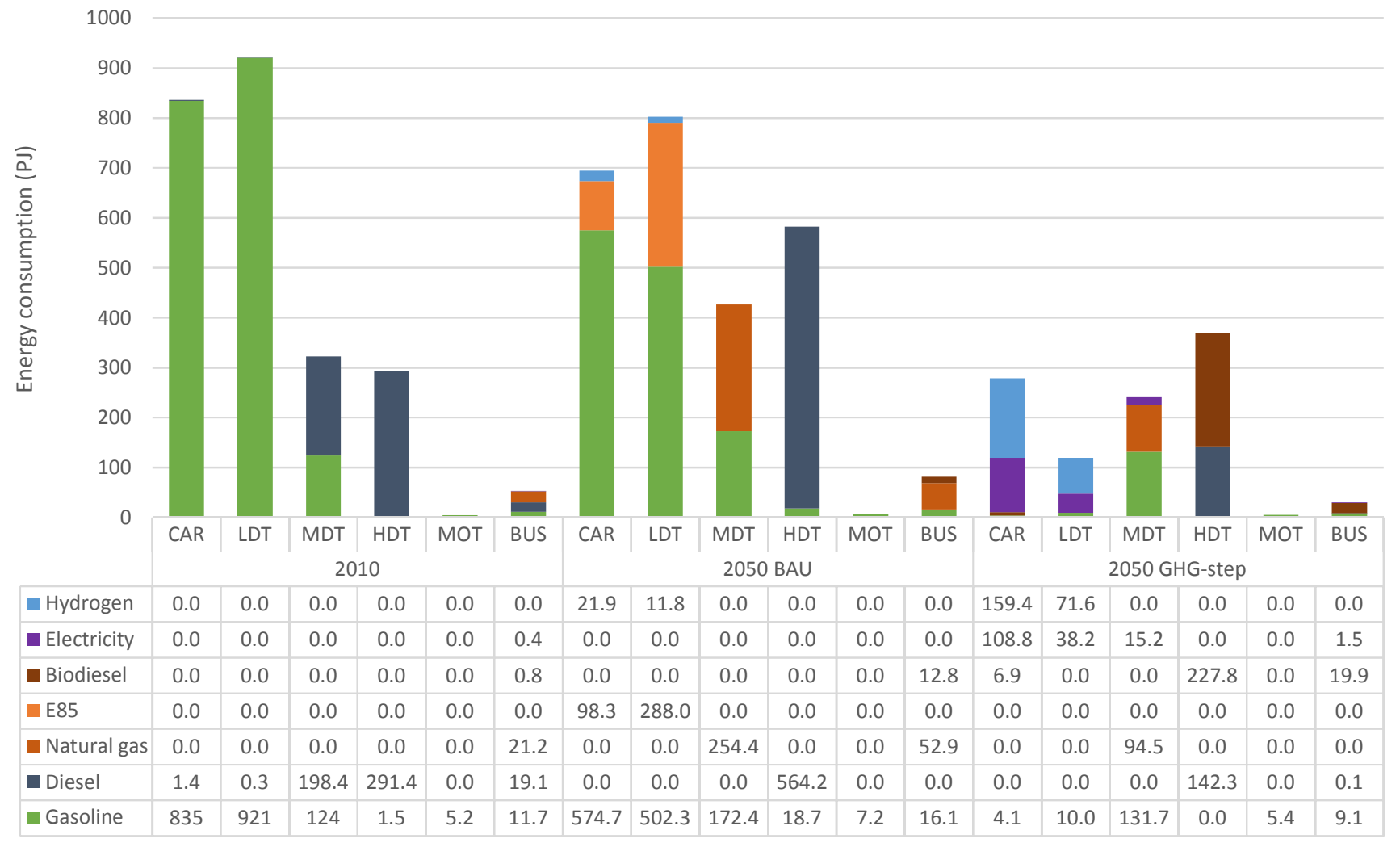

Figure 4. CA-TIMES energy consumption by vehicle weight class, fuel, and scenario for on-road sources. Vehicle categories include car, light-duty truck (LDT), medium-duty truck (MDT), heavy-duty truck (HDT), motorcycles (MOT), and bus.

(a) Catalyst gasoline vehicle

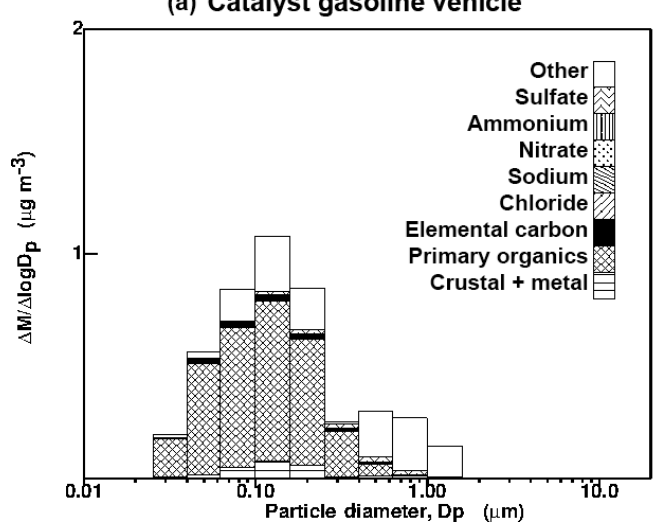

(b) Catalyst ethanol (e85vol) vehicle

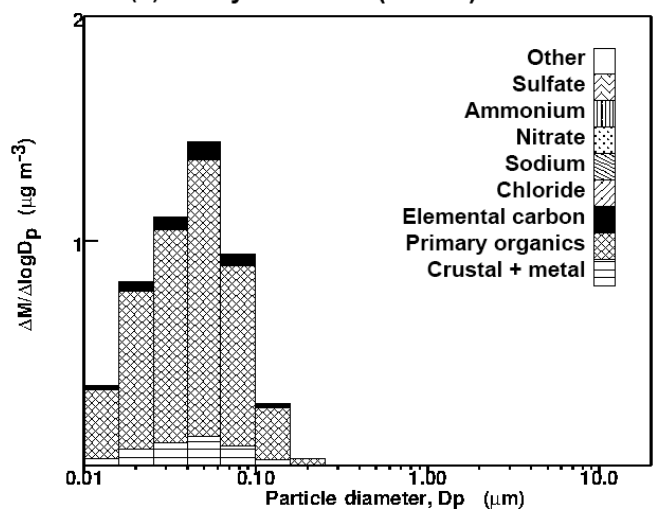

Figure 5. Particle emissions size and composition distribution for catalyst-equipped gasoline vehicles (a) and catalyst-equipped ethanol (E85) vehicles (b).

that vehicle as defined by each CA-TIMES scenario.

$$
\begin{aligned}
& \mathrm{em}_{\mathrm{v}}=\sum_{\mathrm{f}}^{n} \underbrace{\mathrm{er}_{\mathrm{v}, \text { ref }} \cdot \frac{\mathrm{er}_{\mathrm{v}, \mathrm{f}}}{\mathrm{er}_{\mathrm{v}, \mathrm{ref}}}} \cdot \underbrace{\operatorname{act}_{\mathrm{v}} \cdot \frac{E_{\mathrm{v}, \mathrm{f}}}{E_{\mathrm{v}}}}, \\
& \text { Alternative Proportion of } \\
& \text { fuel/energy activity by } \\
& \text { emissions rate fuel/energy } \\
& \text { for vehicle }
\end{aligned}
$$

where $\mathrm{v}$ is vehicle type by weight; $\mathrm{f}$ is unconventional or alternative fuel type from $f_{1}, f_{2}, f_{3} \ldots n$; ref is reference (conventional) fuel, typically gasoline or diesel; $\mathrm{em}_{\mathrm{V}}$ is emissions ( $\mathrm{t}$ per day) of $\mathrm{ROG}, \mathrm{CO}, \mathrm{NO}_{x}, \mathrm{PM}_{10}$, and $\mathrm{SO}_{x}$ for a given vehicle type; $\mathrm{er}_{\mathrm{v} \text {, ref }}$ is pollutant emissions rate for a vehicle using the reference (conventional) fuel based from EMFAC ( $t$ of pollutant $\mathrm{VMT}^{-1}$ or $\mathrm{t}$ of pollutant vehicle ${ }^{-1}$ ); $\mathrm{er}_{\mathrm{v}} \mathrm{f}$ is pollutant emissions rate for a vehicle using an alternative 

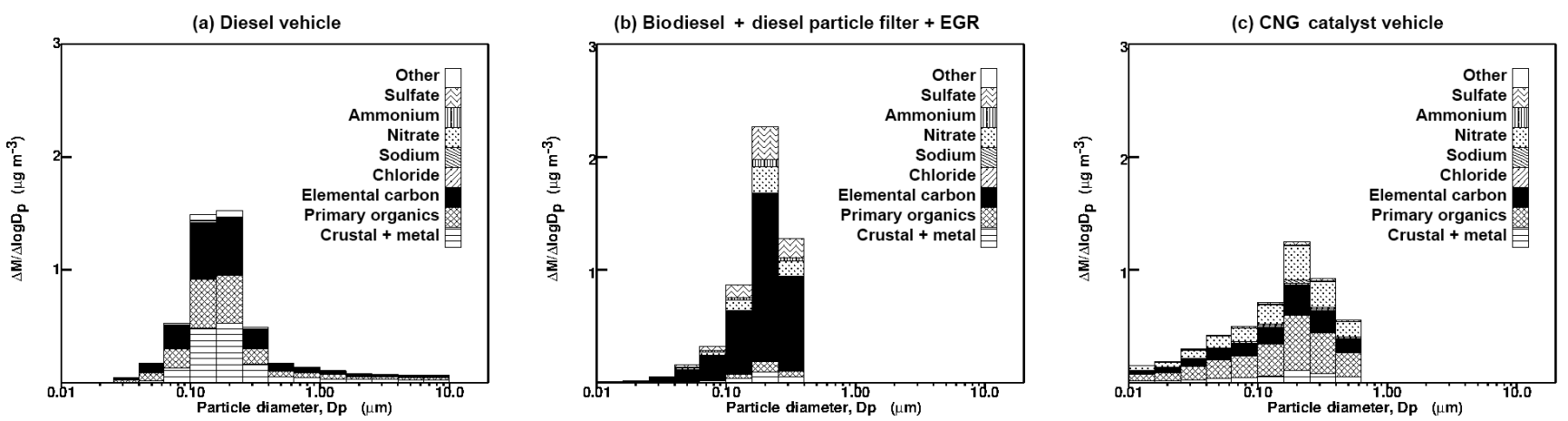

Figure 6. Particle emissions size and composition distribution for diesel vehicles (a), biodiesel vehicles (b), and CNG catalyst-equipped vehicles (c).

(a) Jet fuel aircraft

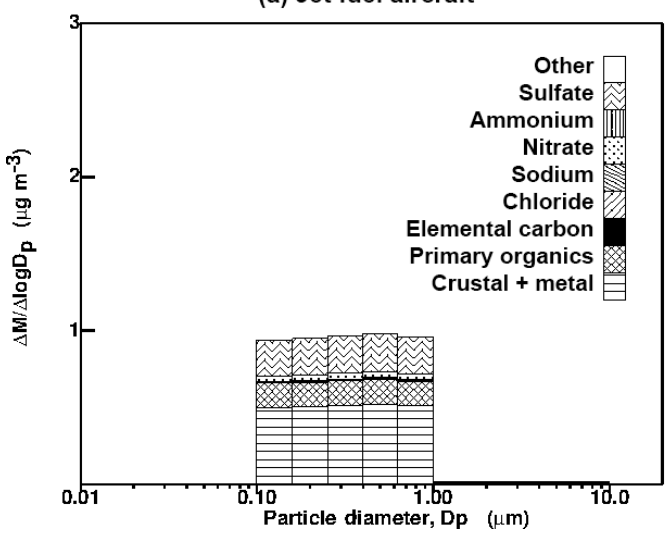

(b) Biomass-based kerosene jet fuel aircraft

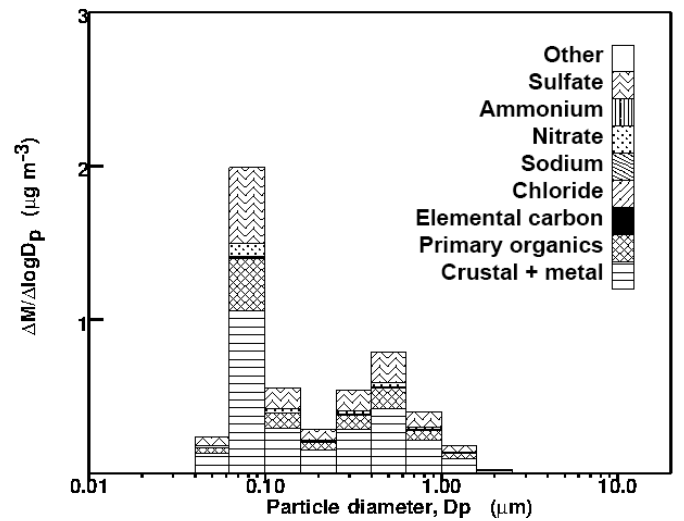

Figure 7. Particle emissions size and composition distribution for jet-fueled aircraft (a) and biomass-based kerosene jet-fueled aircraft (b).

fuel based from EMFAC ( $\mathrm{t}$ of pollutant $\mathrm{VMT}^{-1}$ or $\mathrm{t}$ of pollutant vehicle ${ }^{-1}$ ); act $_{\mathrm{v}}$ is total vehicular activity (not divided by fuel) (VMT or vehicles); $e_{\mathrm{v}}$, is energy consumption for a given fuel by vehicle given by CA-TIMES scenario (PJ); and $e_{\mathrm{V}}$ is total energy consumed for vehicle for all fuels by CA-TIMES scenario (PJ).

Alternative fuels considered by CA-TIMES include $95 \%$ volume blend methanol (M95), $85 \%$ volume blend ethanol (E85), compressed natural gas (CNG), liquid petroleum gas (LPG), biodiesel, compressed or liquid hydrogen, and electric drivetrains. Electric vehicles include hybrid, plug-in hybrid, and plug-in or battery hybrid. CA-TIMES often selected the use of multiple technologies and fuels within the same vehicle weight class (see Tables S4 through Table S12 in the Supplement for complete lists). For example, in the case of a hybrid diesel-electric vehicle which runs on three energy sources, diesel, biodiesel, and electricity (e.g., a biodiesel plug-in hybrid MDT), three sets of emissions rates (one for each fuel) were estimated to replace the single emissions rate for the traditional compression ignition (CI) engine for this vehicle class (diesel MDT).

Only approximately $10 \%$ of the possible vehicle typefuel-engine combinations considered by CA-TIMES (see
Tables S4 to S12 in the Supplement) were actually used in the 2050 BAU and GHG-Step scenarios as the model was optimized for low-cost and low-carbon solutions. The main alternative liquid or gaseous fuels projected by CA-TIMES were E85, biodiesel, and CNG. CA-TIMES predicted that E85 would displace gasoline while biodiesel and CNG would displace diesel based on the dominant fuel consumed for the same vehicle weight class counterpart. This fuel substitution alters emissions rates for criteria pollutants as shown in Table 1. For battery electric or fuel cell vehicles, the conventional fuel displaced was based on the dominant fuel for that vehicle class, e.g., gasoline for LDVs.

\subsubsection{On-road mobile particulate matter and gas speciation and size profile changes}

Tailpipe exhaust, fuel-tank evaporative, and brake-wear emissions were adjusted when the vehicle fuel or technology was changed. This requires new source profiles to be defined for E85-, biodiesel-, and CNG-fueled vehicles to describe their emissions of speciated VOCs and size- and composition-resolved PM. New EICs were created (summarized in Table S13 in the Supplement) and associated with 

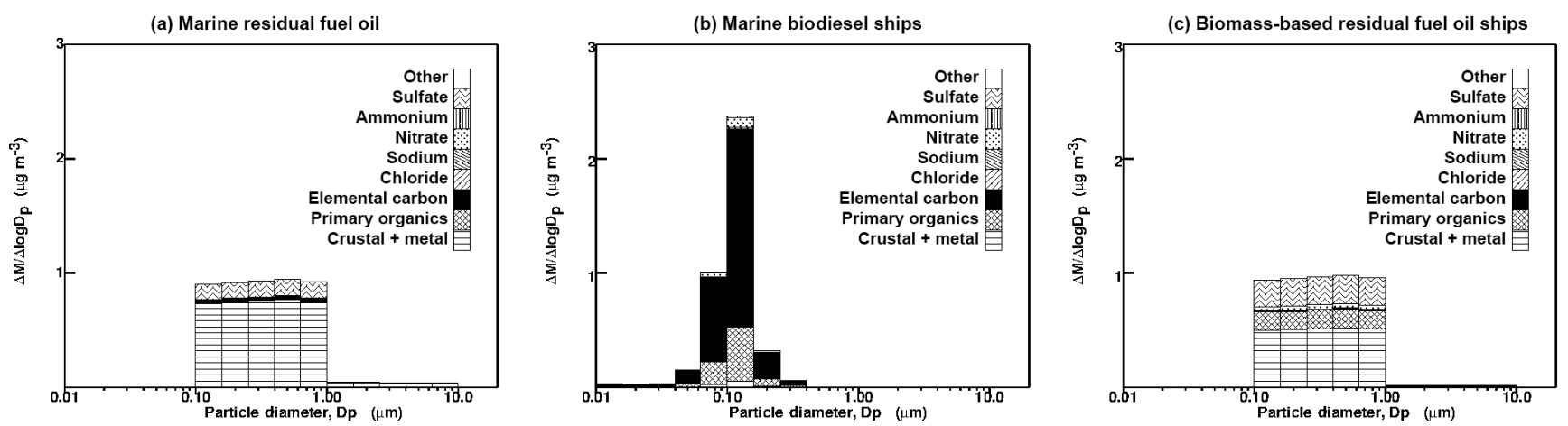

Figure 8. Particle emissions size and composition distribution for ships powered by marine residual oil (a), marine biodiesel (b), and biomass-based residual fuel oil (c).

new VOC and PM emissions profiles (summarized in Tables S14 - S16) for this purpose.

Multiple measurements are available in the literature for the composition of exhaust from ethanol-fueled vehicles. In the present study, the average VOC profiles measured using the Federal Test Procedure, Unified Cycle, and US06 highspeed drive cycles were used for the hot-running E85 VOC exhaust (Haskew and Liberty, 2011). The Federal Test Procedure phase 1 profile was applied for the cold-start E85 VOC emissions (Haskew and Liberty, 2011). E85 PM size distributions are summarized in Table S15 in the Supplement (Szybist et al., 2011) while PM composition information is summarized in Table S16 in the Supplement (Ferreira da Silva et al., 2010; Hays et al., 2013). Figure 5 illustrates the size and composition distribution of PM emitted from catalystequipped gasoline vehicles and catalyst-equipped vehicles fueled by $85 \%$ ethanol and $15 \%$ gasoline (E85) as an example.

Aftertreatment devices were found to be more influential on biofuel exhaust rates (Alleman et al., 2005; Alleman et al., 2004; Frank et al., 2007; Hasegawa et al., 2007; Rounce et al., 2012; Tsujimura et al., 2007) than changes to fuel properties and feedstock origin (Durbin et al., 2007; Graboski et al., 2003). Diesel particulate filters, exhaust gas recirculation, selective catalytic reduction, and oxidation catalyst (OC) were assumed to be deployed on diesel- and biodieselpowered vehicles by 2050. PM size distributions for vehicles equipped with diesel particle filters were obtained from Rounce et al. (2012) (Table S15 in the Supplement), and trace element, carbonaceous, and inorganic ion fractions of PM distributions were obtained from Cheung et al. (2010) and Cheung et al. (2009) (see Table S16 in the Supplement). Gas-phase VOC emissions profiles for biodiesel were not updated from fossil diesel profiles in the current study, but this change will be considered in future work.

The CNG VOC profile and PM size distribution was constructed based on Gautam (2011) (Tables S14 and S15). PM emissions of carbonaceous compounds, metals, and ions were measured from $\mathrm{CNG}$ vehicles running on the Urban
Dynamometer Drive Schedules (UDDS) driving cycle (Yoon et al., 2014) (see Table S16 in the Supplement). Figure 6 illustrates the size and composition distribution of PM emitted from diesel vehicles, biodiesel vehicles equipped with a diesel particle filter and exhaust gas recirculation, and catalyst-equipped $\mathrm{CNG}$ vehicles.

All fully electric vehicles, such as battery electric vehicles and $\mathrm{H}_{2}$ fuel cell vehicles, were assumed to have zero tailpipe exhaust and evaporative emissions rates. Brake-wear emissions rates were reduced by $59 \%$ (Antanaitis, 2010) for all partial or fully electric vehicles equipped with regenerative breaking, such as hybrid, electric battery, or fuel cell vehicles. Tire-wear emissions were assumed to be independent of fuel or technology type.

\subsection{CA-REMARQUE aviation, rail, and off-road algorithms}

Aviation sources include commercial, civil, agricultural, or military use and primarily run on jet fuel or aviation gasoline. The rail emissions sources include passenger, commuter, switching, and hauling trains, which currently run primarily on diesel-fueled generators powering an electric drivetrain. Off-road equipment includes industrial, agricultural, and construction equipment; port and rail operations; and lawn and garden equipment. The list of aviation, rail, and off-road emissions source categorizations are based on the EICs listed in Table S17 in the Supplement (including new EICs created to represent sources operating on alternative fuels previously not in the CARB inventory).

\subsubsection{VISION model}

Future 2050 emissions for aviation, rail, and off-road equipment were assumed to follow the 2010 vs. 2050 growth projected by the CARB VISION model (California Air Resources Board, 2012a), an off-road expansion of Argonne's on-road VISION model (Argonne National Laboratory Transportation Technology R\&D Center, 2012). CARB's off-road VISION model uses historical trends to 
Table 1. Emissions rate changes for alternative fuels in on-road vehicles. Alternative fuels include an $85 \%$ ethanol and $15 \%$ gasoline mixture (E85), biodiesel (B100), and compressed natural gas. Conventional fuels include gasoline, diesel, or ultra-low-sulfur diesel (USLD). Aftertreatment devices include a three-way catalyst (TWC), a diesel oxidation catalyst (DOC), a diesel particle filter (DPF), exhaust gas recirculation (EGR), and selective catalytic reduction (SCR).

\begin{tabular}{|c|c|c|c|c|c|c|}
\hline $\begin{array}{l}\text { Alternative } \\
\text { fuel }\end{array}$ & $\begin{array}{l}\text { Reference } \\
\text { conventional } \\
\text { fuel }\end{array}$ & $\begin{array}{l}\text { After- } \\
\text { treatment }\end{array}$ & Pollutant & $\begin{array}{l}\text { Alt/ } \\
\text { conv } \\
\text { ratio }\end{array}$ & $\begin{array}{l}\text { Conv } \\
\% \\
\text { change }\end{array}$ & Data source \\
\hline \multirow[t]{5}{*}{ E85 } & Gasoline & $\begin{array}{l}\text { Same } \\
\text { (TWC) }\end{array}$ & $\mathrm{CO}$ & 1.00 & $0.0 \%$ & Graham et al. (2008) \\
\hline & & & $\mathrm{NO}_{x}$ & 0.55 & $-45 \%$ & Graham et al. (2008) \\
\hline & & & $\mathrm{SO}_{x}$ & 1.00 & $0.0 \%$ & Assumed \\
\hline & & & ROG & 1.00 & $0.0 \%$ & Graham et al. (2008) \\
\hline & & & PM & 0.25 & $-75 \%$ & Hays et al. (2013) \\
\hline \multirow[t]{5}{*}{ B100 } & $\begin{array}{l}\text { Diesel or } \\
\text { ULSD }\end{array}$ & $\begin{array}{l}\text { DOC+ } \\
\text { DPF+ } \\
\text { EGR+ } \\
\text { SCR }\end{array}$ & $\mathrm{CO}$ & 0.03 & $-97 \%$ & $\begin{array}{l}\text { Alleman et al. (2004), } \\
\text { Alleman et al. (2005), } \\
\text { Hasegawa et al. (2007) }\end{array}$ \\
\hline & & & $\mathrm{NO}_{x}$ & 0.85 & $-15 \%$ & $\begin{array}{l}\text { Alleman et al. (2004), } \\
\text { Alleman et al. (2005), } \\
\text { Tsujimura et al. (2007) }\end{array}$ \\
\hline & & & $\mathrm{SO}_{x}$ & 1.00 & $0.0 \%$ & Assumed \\
\hline & & & ROG & 0.03 & $-97 \%$ & $\begin{array}{l}\text { Alleman et al. (2004), } \\
\text { Alleman et al. (2005), } \\
\text { Hasegawa et al. (2007) }\end{array}$ \\
\hline & & & PM & 0.03 & $-97 \%$ & $\begin{array}{l}\text { Alleman et al. (2004), } \\
\text { Alleman et al. (2005), } \\
\text { Hasegawa et al. (2007), } \\
\text { Rounce et al. (2012) }\end{array}$ \\
\hline \multirow[t]{5}{*}{ CNG } & $\begin{array}{l}\text { Diesel or } \\
\text { ULSD }\end{array}$ & TWC & $\mathrm{CO}$ & 0.67 & $-33 \%$ & Cooper et al. (2012) \\
\hline & & & $\mathrm{NO}_{x}$ & 0.19 & $-81 \%$ & Cooper et al. (2012) \\
\hline & & & $\mathrm{SO}_{x}$ & 1.00 & $0.0 \%$ & Assumed \\
\hline & & & ROG & 0.34 & $-66 \%$ & Cooper et al. (2012) \\
\hline & & & PM & 0.08 & $-92 \%$ & Cooper et al. (2012) \\
\hline
\end{tabular}

project to the year 2050 while incorporating some future standards for criteria pollutant emissions rates. These include the implementation of Tier $4130-560 \mathrm{~kW}$ compressionignition diesel engine emissions standards for PM, CO, and $\mathrm{NMHC}+\mathrm{NO}_{x}$ (California Air Resources Board, 2010a), leading to $90 \%$ reduction in $\mathrm{PM}$ emissions rates and an $85 \%$ reduction in $\mathrm{NMHC}$ and $\mathrm{NO}_{x}$ emissions rates.

Aviation, rail, and off-road 2010 emissions at $4 \mathrm{~km}$ resolution $\left(\mathrm{em}_{\text {cell,II }}^{2010}\right)$ were scaled to produce an intermediate esti- mate prior to CA-TIMES adjustments using Eq. (5).

$$
\mathrm{em}_{\text {cell, } \mathrm{i}, \text { intermediate }}^{2050}=\underbrace{\left(\frac{\mathrm{em}_{\mathrm{i}}^{2050}}{\mathrm{em}_{\mathrm{i}}^{2010}}\right)}_{\begin{array}{c}
\text { Statewide } \\
\text { emissions growth } \\
\text { scaling from } \\
2010 \text { to } 2015
\end{array}} \cdot \mathrm{em}_{\text {cell, } \mathrm{i}}^{2010},
$$

where $\mathrm{em}_{\text {cell, } \mathrm{i} \text {, intermediate }}^{2050}$ is intermediate grid cell 2050 emissions for a transport source (aviation, rail, off-road) consuming a reference or conventional fuel or energy $\left(\mathrm{kg} \mathrm{h}^{-1}\right)$, 
$\mathrm{em}_{\mathrm{i}}^{2050}$ is statewide 2050 emissions of a transport source $\left(\mathrm{kg} \mathrm{h}^{-1}\right.$ or t day $\left.{ }^{-1}\right), \mathrm{em}_{\mathrm{i}}^{2010}$ is statewide 2010 emissions of a transport source $\left(\mathrm{kg} \mathrm{h}^{-1}\right.$ or $\left.\mathrm{tday}^{-1}\right)$, and $\mathrm{em}_{\text {cell, } \mathrm{i}}^{2010}$ is grid cell 2010 emissions of a transport source $\left(\mathrm{kg} \mathrm{h}^{-1}\right)$.

\subsubsection{CA-TIMES modification of intermediate 2050 off-road mobile emissions}

The portion of energy consumed for each fuel $\left(E_{\mathrm{i}, \mathrm{f}} / \Sigma_{\mathrm{f}} E_{\mathrm{i}, \mathrm{f}}\right)$ as projected by CA-TIMES was applied to the intermediate 2050 emissions inventory for each transport mode (f) and source type (i) using Eq. (6). The consumption of different fuels relative to total fuel consumption for a given mode is shown in Figs. S1-S3 for rail, off-road, and aviation modes, respectively. Alternatives to conventional scaling factors were applied to account for the adoption of alternative fuels as summarized in Table 2. Equation (6) also includes an aftertreatment or control device factor $(1-\eta)$ where appropriate.

$$
\mathrm{SF}_{\mathrm{i}, \mathrm{f}}=\underbrace{\left(\frac{E_{\mathrm{i}, \mathrm{f}}}{\sum_{\mathrm{f}} E_{\mathrm{i}, \mathrm{f}}}\right)}_{\begin{array}{c}
\text { Portion of } \\
\text { alternative } \\
\text { fuel energy } \\
\text { consumption }
\end{array}} \cdot \underbrace{\left(\frac{\mathrm{em}_{\mathrm{i}, \mathrm{f}}^{2050}}{\mathrm{em}_{\mathrm{i}, \text { intermediate }}^{2050}}\right)}_{\begin{array}{c}
\text { Alternative fuel } \\
\text { emissions scaling } \\
\text { relative to } \\
\text { conventional }
\end{array}} \cdot \underbrace{\left(1-\eta_{\mathrm{i}}\right)}_{\begin{array}{c}
\text { Fraction of } \\
\text { pollutant not } \\
\text { removed by } \\
\text { aftertreatment } \\
\text { device }
\end{array}},
$$

where $\mathrm{SF}_{\mathrm{i}, \mathrm{f}}$ is the emissions scaling factor for a given new or alternative or nonconventional or non-reference fuel for a transport source (dimensionless), $E_{\mathrm{i}, \mathrm{f}}$ is new or alternative fuel or energy consumed by a transport source (e.g., biodiesel for commuter rail) $(\mathrm{PJ}), \sum_{\mathrm{f}} E_{\mathrm{i}, \mathrm{f}}$ is total fuel or energy consumed by a transport source (e.g., biodiesel + diesel for commuter rail) (PJ), $\mathrm{em}_{\mathrm{i}, \mathrm{f}}^{2050}$ is statewide 2050 emissions of a transport source consuming a new or alternative fuel $\left(\mathrm{kg} \mathrm{h}^{-1}\right.$ or t day $\left.{ }^{-1}\right), \mathrm{em}_{\mathrm{i} \text {, intermediate }}^{2050}$ is statewide 2050 intermediate emissions of a transport source consuming a new or alternative fuel $\left(\mathrm{kg} \mathrm{h}^{-1}\right.$ or t day $\left.{ }^{-1}\right)$, and $\eta_{\mathrm{i}}$ is efficiency of removal from a control or aftertreatment device (fraction from 0.00 to 1.00$)$.

The final emissions for each specific off-road source consuming each specific fuel in $2050\left(\mathrm{em}_{\text {cell, }}^{2050}, \mathrm{f}\right)$ are then calculated by combining the effects of the VISION and CATIMES updates as shown in Eq. (7).

$\mathrm{em}_{\text {cell, } \mathrm{i}, \mathrm{f}}^{2050}=\mathrm{SF}_{\mathrm{i}, \mathrm{f}} \cdot \mathrm{em}_{\text {cell, }}^{2050}$, intermediate

Aviation biomass-based kerosene jet fuel (KJF) emissions changes are based on Fischer-Tropsch gas-to-liquid biofuel aviation emissions tests (Lobo et al., 2011, 2012). These studies found minor changes to $\mathrm{CO}$ and $\mathrm{NO}_{x}$ emissions due to the adoption of biofuels. $\mathrm{SO}_{x}$ reduction was assumed proportional to the fuel sulfur content (Lobo et al., 2012), leading to reductions of $99 \%$ as shown in Table 2.

Off-road equipment (other than trains) operating on biodiesel instead of ultra-low-sulfur diesel (ULSD) was assumed to emit $\mathrm{HC}$ and $\mathrm{NO}_{x}$ with scaling factors (relative to conventional diesel emissions) of 0.39 and 1.08 , respectively (Durbin et al., 2007). No significant changes in $\mathrm{CO}, \mathrm{SO}_{x}$ and PM due to the adoption of biodiesel vs. ULSD were identified in the literature and so these emissions were assumed to remain at levels estimated for conventional diesel engines. This approach inherently assumes that the sulfur content of biodiesel will not exceed the current limit of $15 \mathrm{ppm}$ for ULSD. Off-road or agricultural emissions changes from switching from diesel to $\mathrm{CNG}$ are also found to have large reductions in most pollutants except for ROGs (Cooper et al., 2012).

Military aviation emissions were held constant at 2010 levels in the current study due to an assumption of continued exemptions for military activity.

\subsubsection{Off-road mobile PM and gas speciation and size profile changes}

PM mass size distributions for E85, biodiesel, and CNG are assumed to be similar for off-road and on-road vehicles (Table S15 in the Supplement). The new PM mass size distribution for biomass-based KJF is shown in Table S18 in the Supplement (Lobo et al., 2011). Figure 7 illustrates the size and composition distribution of PM emitted from conventional jet-fuel aircraft and biomass-based KJF aircraft. The conventional profile is based on old source profile measurements that assumed uniform distribution of particles between the diameters of 0.1 and $1.0 \mu \mathrm{m}$. This conventional profile will be updated with more recent literature values in future work.

\subsection{CA-REMARQUE marine algorithms}

The marine emissions source category includes all oceangoing vessels (OGVs), commercial harbor craft, and recreational boats (see Table S19 in the Supplement). An intermediate OGV emissions inventory was predicted for the year 2050 based on the extrapolation of Port of Los Angeles and Port of Long Beach 2020 trends (Starcrest Consulting Group, 2009; The Port of Los Angeles and The Port of Long Beach, 2010) (see Table S20 in the Supplement). All other OGV emissions (not listed in Table S20 in the Supplement) in California were held constant at 2010 levels in the intermediate 2050 inventory prior to modifications from CA-TIMES.

\subsubsection{CA-TIMES modification of intermediate 2050 marine emissions}

The fuels used to power OGVs were modified based on predictions from the CA-TIMES scenarios. It should be noted that the CA-TIMES model reports worldwide marine energy consumption. In the current study, it was assumed that marine vessels operating near the California coast would consume the global average mix of biofuels produced by CATIMES. For example, if CA-TIMES indicated that a third of the residual fuel oil (RFO) (also call heavy fuel oil) consumed globally by marine vessels was converted to biomass- 
Table 2. Emissions rate changes for alternative fuels in off-road vehicles.

\begin{tabular}{|c|c|c|c|c|c|c|}
\hline $\begin{array}{l}\text { Transport } \\
\text { mode }\end{array}$ & $\begin{array}{l}\text { Alternative } \\
\text { fuel }\end{array}$ & $\begin{array}{l}\text { Reference } \\
\text { conven- } \\
\text { tional } \\
\text { fuel }\end{array}$ & Pollutant & $\begin{array}{l}\text { Alt/ } \\
\text { conv } \\
\text { ratio }\end{array}$ & $\begin{array}{l}\text { Conv } \\
\% \\
\text { change }\end{array}$ & Citations \\
\hline \multirow[t]{5}{*}{ Rail } & \multirow[t]{5}{*}{ Biodiesel } & \multirow[t]{5}{*}{ Diesel } & $\mathrm{CO}$ & 0.655 & $-34.5 \%$ & Osborne et al. (2010) \\
\hline & & & $\mathrm{NO}_{x}$ & 1.13 & $13 \%$ & Osborne et al. (2010) \\
\hline & & & $\mathrm{SO}_{x}$ & 0.0005 & $-99.95 \%$ & Assumed (see text) \\
\hline & & & ROG & 0.775 & $-22.5 \%$ & Osborne et al. (2010) \\
\hline & & & PM & 0.805 & $-19.5 \%$ & Osborne et al. (2010) \\
\hline \multirow{10}{*}{$\begin{array}{l}\text { Off-road/ } \\
\text { agricultural }\end{array}$} & \multirow[t]{5}{*}{ Biodiesel } & \multirow[t]{5}{*}{ Diesel } & $\mathrm{CO}$ & 1 & $0 \%$ & Durbin et al. (2007) \\
\hline & & & $\mathrm{NO}_{x}$ & 1.08 & $8 \%$ & Durbin et al. (2007) \\
\hline & & & $\mathrm{SO}_{x}$ & 1 & $0 \%$ & Durbin et al. (2007) \\
\hline & & & ROG & 0.39 & $-61 \%$ & Assumed (see text) \\
\hline & & & PM & 1.13 & $13 \%$ & Durbin et al. (2007) \\
\hline & \multirow[t]{5}{*}{$\begin{array}{l}\text { Compressed } \\
\text { natural gas }\end{array}$} & \multirow[t]{5}{*}{ Diesel } & $\mathrm{CO}$ & 0.668 & $-33.2 \%$ & Cooper et al. (2012) \\
\hline & & & $\mathrm{NO}_{x}$ & 0.189 & $-81.1 \%$ & Cooper et al. (2012) \\
\hline & & & $\mathrm{SO}_{x}$ & 1 & $0 \%$ & Assumed (see text) \\
\hline & & & ROG & 2.349 & $134.9 \%$ & Cooper et al. (2012) \\
\hline & & & PM & 0.0782 & $-92.18 \%$ & Cooper et al. (2012) \\
\hline \multirow[t]{5}{*}{ Aviation } & \multirow{5}{*}{$\begin{array}{l}\text { Biomass- } \\
\text { based } \\
\text { kerosene } \\
\text { jet fuel }\end{array}$} & \multirow[t]{5}{*}{$\begin{array}{l}\text { Kerosene } \\
\text { jet fuel }\end{array}$} & $\mathrm{CO}$ & 1 & $0 \%$ & Lobo et al. (2012) \\
\hline & & & $\mathrm{NO}_{x}$ & 1 & $0 \%$ & Lobo et al. (2012) \\
\hline & & & $\mathrm{SO}_{x}$ & 0.007 & $-99.3 \%$ & Assumed (see text) \\
\hline & & & ROG & 0.605 & $-39.5 \%$ & Lobo et al. (2012) \\
\hline & & & PM & 0.38 & $-62 \%$ & Lobo et al. (2011) \\
\hline
\end{tabular}

based residual fuel oil (BRFO) in the future, then a third of the RFO marine vessel emissions near California boundaries would also be converted to BRFO. As indicated by Fig. S4 in the Supplement, CA-TIMES finds that other approaches in addition to biofuel adoption for ships are more cost effective for meeting the GHG target in 2050. CA-TIMES determined that it will be more economical to substitute some RFO with a lighter petroleum (diesel) to decrease carbon intensity rather than using BRFO.

Alternative fuels used in marine sources will modify criteria pollutant emissions. Biomass-based alternatives for marine RFO were estimated to be similar to the average of B100 from palm oil, animal fat, soybean oil, and sunflower oil operating at $75 \%$ load (Petzold et al., 2011). $\mathrm{NO}_{x}$ was the only regulated pollutant observed to remain constant during emissions testing. Emissions of all other pollutants decreased as summarized in Table 3.

Assuming biodiesel and BRFO has about $1 \mathrm{ppm}$ of sulfur content, and that by 2010 the sulfur content regulations ensured that marine diesel oil (MDO) and RFO had $1.5 \mathrm{ppm}$ and $2.5 \mathrm{ppm}$ of $\mathrm{S}$, respectively, then the switch to biofuels would reduce $\mathrm{SO}_{x}$ emissions by $33.3 \%$ (relative to conventional MDO) and $60 \%$ (relative to conventional RFO). Additional reductions in $\mathrm{CO}$, total organic gas (TOG), and PM were also projected based on Jayaram et al. (2011) and Petzold et al. (2011) as summarized in Table 3.

Several international and California shoreline regulations were applied to marine emissions in the year 2050 as summa- 
Table 3. Emissions rate changes from ships changing from conventional fuels to biofuels.

\begin{tabular}{|c|c|c|c|c|c|}
\hline $\begin{array}{l}\text { Alternative } \\
\text { fuel }\end{array}$ & $\begin{array}{l}\text { Reference } \\
\text { conventional } \\
\text { fuel }\end{array}$ & Pollutant & $\begin{array}{l}\text { Alt/ } \\
\text { conv } \\
\text { ratio }\end{array}$ & $\begin{array}{l}\text { Conv } \\
\% \\
\text { change }\end{array}$ & Citations \\
\hline \multirow{5}{*}{$\begin{array}{l}\text { Biomass- } \\
\text { based } \\
\text { residual fuel } \\
\text { oil }\end{array}$} & $\begin{array}{l}\text { Residual } \\
\text { fuel } \\
\text { oil }\end{array}$ & $\mathrm{CO}$ & 0.697 & $-30.3 \%$ & Petzold et al. (2011) \\
\hline & & $\mathrm{NO}_{x}$ & 1 & $0 \%$ & Petzold et al. (2011) \\
\hline & & $\mathrm{SO}_{x}$ & 0.012 & $-98.8 \%$ & Petzold et al. (2011) \\
\hline & & ROG & 0.413 & $-58.7 \%$ & Petzold et al. (2011) \\
\hline & & PM & 0.223 & $-77.7 \%$ & Petzold et al. (2011) \\
\hline \multirow[t]{5}{*}{ Biodiesel } & Diesel & $\mathrm{CO}$ & 0.921 & $-7.9 \%$ & Jayaram et al. (2011) \\
\hline & & $\mathrm{NO}_{x}$ & 1 & $0 \%$ & Jayaram et al. (2011) \\
\hline & & $\mathrm{SO}_{x}$ & 0.0003 & $-99.97 \%$ & Assumed (see text). \\
\hline & & ROG & 1 & $0 \%$ & Jayaram et al. (2011) \\
\hline & & PM & 0.684 & $-31.6 \%$ & Jayaram et al. (2011) \\
\hline
\end{tabular}

rized in Tables S21 and S22. At-berth or hotelling container, passenger (cruise), and refrigeration OGVs will use shoreline power instead of auxiliary engines for $80 \%$ of their berthing hours by 2020 (California Air Resources Board, 2007). It was also assumed that MDO or marine gasoline oil used within 24 nautical miles of the California shore will have a sulfur content of $<0.1 \%$ by 2050 (California Air Resources Board, 2011e). Further offshore, all marine fuels used within 100 nautical miles of North America were assumed to have a sulfur content $<1 \%$ after the year 2012 (leading to the reductions shown in Table 3 ).

\subsubsection{Marine PM and gas speciation and size profile changes}

PM size distribution changes caused by the switch to alternative marine fuels were based on Jayaram et al. (2011) (see Table S23 in the Supplement). The size and composition distribution profiles used to represent marine emissions associated with different fuels are displayed in Fig. 8.

\subsection{CA-REMARQUE residential and commercial algorithms}

Major emissions sources within the residential and commercial sectors include natural gas combustion (space heating and water heating), biomass combustion (fireplaces and stoves), and food cooking (especially charbroiling and frying). The residential and commercial emissions associated with natural gas and food cooking were assumed to scale according to population growth projected for each county
(Table S24 in the Supplement) (State of California, 2013) to produce an intermediate emissions inventory. These intermediate residential and commercial gridded emissions were then scaled to reflect 2010 vs. 2050 results from CA-TIMES (Fig. 9).

Natural gas consumption in the commercial sector was reduced by half ( 325 to $162 \mathrm{PJ}$ ) in the GHG-Step scenario relative to the BAU scenario in 2050. Most of commercial energy reduction is due to efficiency gains and switch from natural gas to electrification of end uses. Natural gas consumption in the residential sector also decreases (615 to $507 \mathrm{PJ})$ under the GHG-Step scenario relative to the BAU scenario. Much of the energy that would have been supplied by natural gas is replaced by renewable sources such as solar (155 PJ), which was assumed to have no criteria pollutant emissions in California. Improved energy efficiency and conservation also plays a role, with residential electricity consumption decreasing (402 to 313 PJ) in the GHG-Step scenario. Other combustion sources, including wood burning and distillate oil fuel consumption, were allowed to compete in CA-TIMES subject to the constraint that they could not increase above the 2010 levels in order to maintain compliance with current air quality regulations.

\subsection{CA-REMARQUE electricity generation algorithms}

The electricity generation emissions category includes all fuel-burning and renewable power plants for industrial, residential, commercial, or transportational use. Annual generation totals for different types of California power plants were 


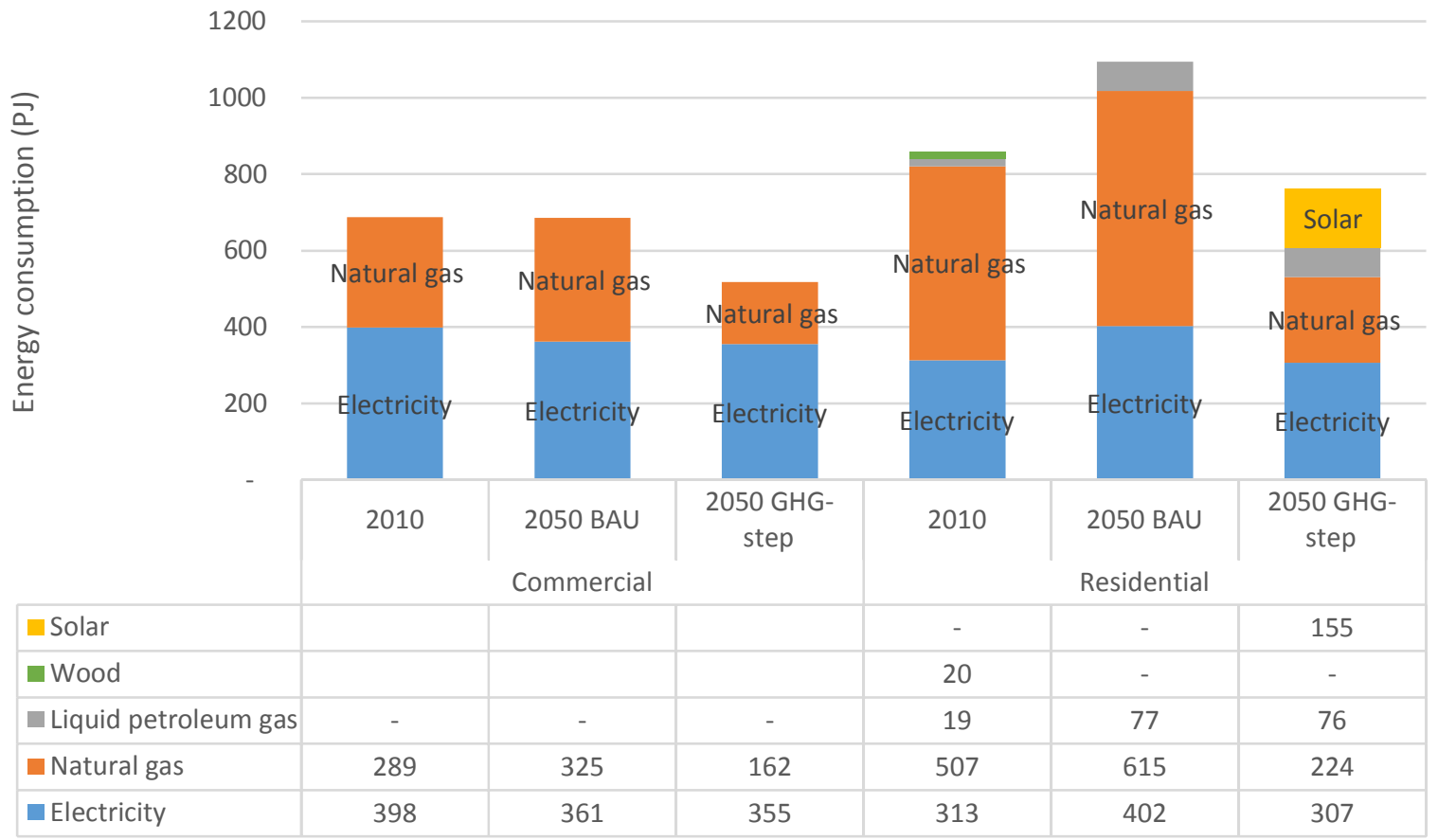

Figure 9. CA-TIMES energy consumption by energy resource and scenario for commercial and residential use.

extracted from national power plant data (US Energy Information Administration Independent Statistics and Analysis, 2012; US Environmental Protection Agency, 2014). Emissions rates per unit of fuel burned were estimated for each power plant described in the base case 2010 emissions inventory.

CA-TIMES finds that non-hydro renewable (geothermal, tidal, solar, wind, and biomass) increases from $10 \%$ $(22938 \mathrm{GWh})$ of the electricity generation mix in 2010 $(144825 \mathrm{GWh})$ to 35 and $76 \%(489493 \mathrm{GWh})$ in the 2050 BAU and 2050 GHG-Step scenarios, respectively (see Fig. 10). However, total in-state and out-of-state electricity generation in the GHG-Step scenario is one-third larger than the BAU scenario (416219 GWh vs. $643373 \mathrm{GWh}$ ) to meet the increased demand from sectors such as the on-road vehicles with growing hybridization and electrification needed to meet the 2050 carbon constraint. Statewide scaling factors for electricity generation in the 2050 BAU scenario vs. 2010 and the 2050 GHG-Step scenario vs. 2010 are listed in Table S25 in the Supplement.

CA-TIMES calculates aggregated statewide energy totals but energy resources (especially for renewables) are not uniformly distributed across the state. In the current study, renewable electricity production in 2050 was spatially allocated in a manner that was consistent with the energy resource potential in 12 regions (Fig. S5 in the Supplement) as projected in 15 scenarios by the grid load distribution model SWITCH (Fripp, 2012; Johnston et al., 2013; Nelson et al., 2013). Table S26 in the Supplement lists the electrical gen- eration by energy source for each SWITCH region averaged across these 15 scenarios. This profile of resource potential was then applied to the CA-TIMES predictions summarized in Table S25 in the Supplement yielding the 2050 and 2010 scaling factors for the BAU scenario (Table S27 in the Supplement) and the GHG-Step scenario (Table S28 in the Supplement).

The scaling factors summarized in Tables S27 and S28 assume that the out-of-state portion of electricity generation for a given fuel or energy resource in the year 2050 remained constant at 2010 levels. CA-TIMES does not provide additional information describing out-of-state generation except for a few renewables. This out-of-state portion of the electricity generation was subtracted from the CA-TIMES totals prior to scaling emissions from each power plant in California. Table S29 in the Supplement summarizes the out-of-state portion of electricity generation for each fuel in 2010 and assumed portions in each of the 2050 scenarios.

Additional emissions adjustments were made for new renewable fuels such as those produced by the biomass integrated gasification combined cycle (IGCC), a process that gasifies biomass for electricity production. Much of the biomass electricity generation projected by CA-TIMES for 2050 in the BAU scenario uses biomass IGCC (see Tables S30 through S32). There are currently several coal IGCC plants in the US (US Department of Energy National Energy Technology Laboratory, 2010, 2015) but no biomass IGCC plants (Lundqvist, 1993; Ståhl and Neergaard, 1998; US Department of Energy National Energy Technology Lab- 


\section{Electricity generation}

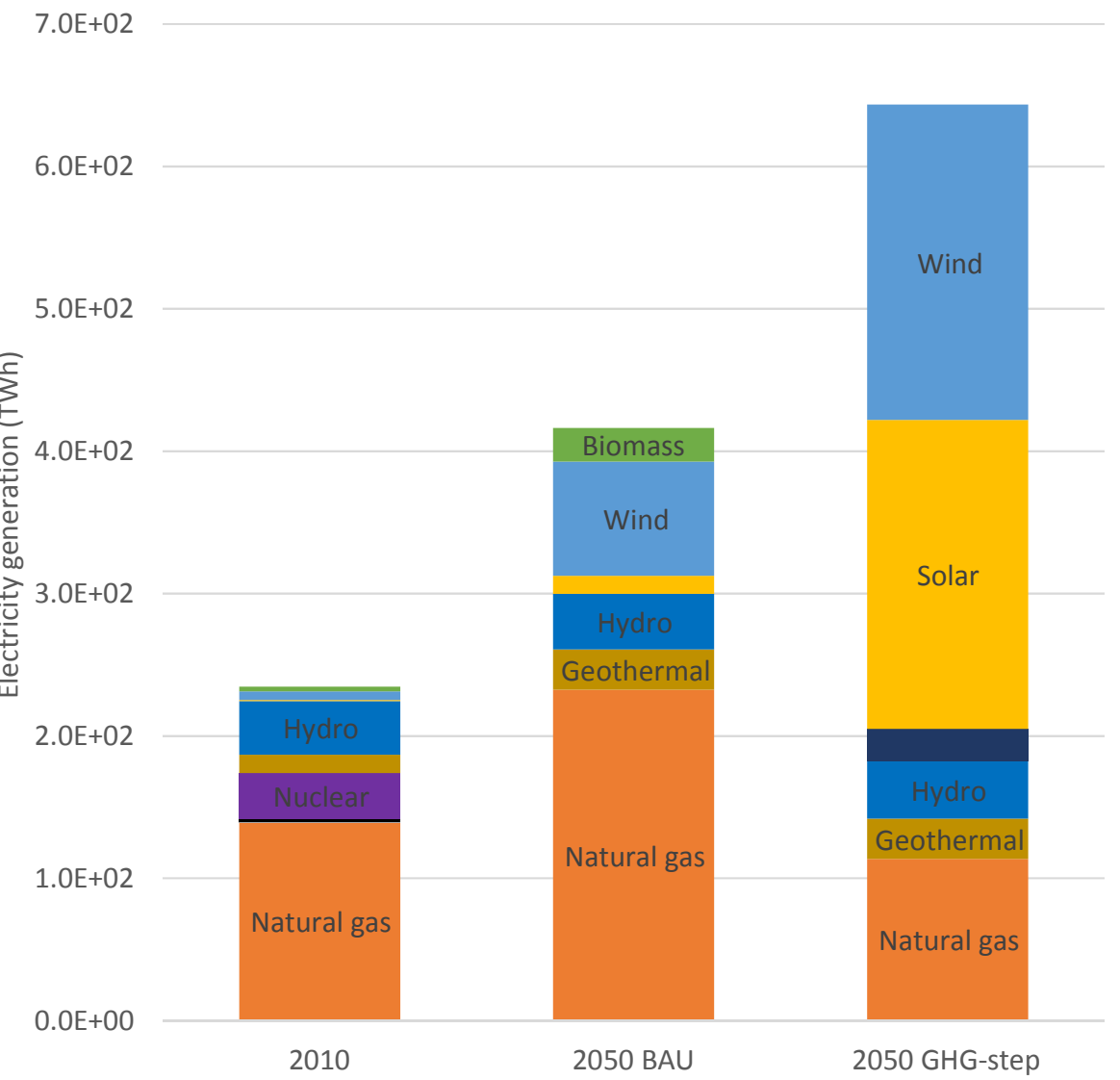

Figure 10. CA-TIMES electricity generation resource mix by scenario.

oratory, 2010). Future biomass IGCC emissions in California were estimated using several models that incorporate biomass IGCC, such as GREET, CA-GREET (Argonne National Laboratory Transportation Technology R\&D Center, 2014; California Air Resources Board, 2009a, 2015), and a National Renewable Energy Laboratory analysis (Mann and Spath, 1997). Ultimately, biomass IGCC power plant emissions were estimated from conversion of conventional steam turbines in the 2010 CARB inventory based on emissions rates inferred from CA-GREET1.8 for 2050 (Table S33 in the Supplement). An inter-comparison study among GREET1.8, GREET 2014, and CA-GREET2.0 showed that the CAGREET1.8b model had the best agreement with emissions rates from approximately 30 biomass plants operating on wood residue in California (California Air Resources Board, 2011b; US Environmental Protection Agency, 2014).

\subsection{CA-REMARQUE industrial and agricultural algorithms}

The industrial and agricultural emissions category covers many manufacturing industries such as metal, wood, glass, textiles, mining, and chemicals. Food and agricultural sectors include farming livestock, crops, food production, bakeries, and breweries. Most of these industries were unchanged in the CA-TIMES energy scenarios, with the notable exception that biofuel and hydrogen fuel production replaced some traditional petroleum production, causing changes in refinery and storage emissions (shown in Figs. S6-S8).

\subsubsection{Fossil and renewable fuel production}

All fossil petroleum refining and storage emissions in the 2010 Air Resources Board emissions inventory were scaled according to the amount of oil production and refining that was required in California for each 2050 CA-TIMES scenario (see Fig. S6 in the Supplement). Scaling factors were applied uniformly to all emissions processes including seepage, evaporative or fugitive, and other processes. Fossil petroleum consumption generally decreased in future scenarios, but was not eliminated. As discussed in previous sections, transportation modes (e.g., marine, HDTs) still consume fossil fuels such as diesel, and the stationary sources (electricity generation, residential, and commercial) still consume natural gas. CA-TIMES determined that much of the extracted petroleum used by refineries would be imported to 
the state rather than extracted locally. This can be seen by the reduction of crude oil supply in California from $1510 \mathrm{PJ}$ in 2010 to $426.5 \mathrm{PJ}$ in the $2050 \mathrm{BAU}$ scenario and $0.0 \mathrm{PJ}$ in the GHG-Step scenario (see Fig. S6 in the Supplement). Refining is also projected to decline slightly between the 2010 and 2050 scenarios, with reductions of $25 \%$ in the BAU scenario and $44 \%$ in the GHG-Step scenario. This suggests that it is more cost effective or less carbon intensive to import fuel than to extract oil and gas in or around California. The total (imported and in-state) oil supply also decreases in 2050, by $-26 \%$ in the BAU (3200 PJ) and $-44 \%$ in the GHG-Step scenario $(2400 \mathrm{PJ})$ relative to $2010(4300 \mathrm{PJ})$. This reflects the adoption of electrification and alternative fuels to replace petroleum consumption in the presence of growing energy demand in 2050.

Hydrogen $\left(\mathrm{H}_{2}\right)$ production increased in both $2050 \mathrm{CA}$ TIMES scenario results, but the increases in the GHG-Step scenario are much larger (Fig. S7 in the Supplement). It was assumed that new hydrogen production facilities would be located at current $\mathrm{H}_{2}$ production facilities or existing refineries. Overall 32 new natural gas steam methane reforming (SMR) $\mathrm{H}_{2}$ facilities and 15 new biomass gasification facilities were projected to meet the demand summarized in Fig. S7 in the Supplement. In the current study, criteria pollutant emissions rates from $\mathrm{SMR} \mathrm{H}_{2}$ production (summarized in Table 4) were calculated from the top three $\mathrm{SMR} \mathrm{H}_{2}$ production facilities (California Air Resources Board, 2010c, 2014). Few studies have been published describing criteria pollutant emissions from biomass gasification $\mathrm{H}_{2}$ production and so emissions rates for this production pathway were obtained from the CA-GREET model (California Air Resources Board, 2015). Direct criteria pollutant emissions from hydrogen production using electrolysis were zero since this process uses electricity to split water molecules into $\mathrm{H}_{2}$ and oxygen (emissions from these facilities appear under electricity generation).

The CA-TIMES model determined that biofuel consumption and production will be high in California in the year 2050 (Fig. S8 in the Supplement). Biofuel refineries for different feedstock classes (wood, municipal solid waste, herbaceous crops, yellow grease or tallow, or corn ethanol) (see Tables S34 and S35) were located using a spatial biomass optimization model which seeks to minimize cost within resource and regulatory constraints (Tittmann et al., 2010). Biofuel refineries were prohibited in NAAQS non-attainment areas, an added constraint based on the high feedstock case described by Parker (2012). Production rates at in-state biorefineries were scaled to match the in-state volumes produced in CA-TIMES for each type of biofuel. Out-of-state imports and refining were assumed for crops that could not be grown at a large enough scale to meet the demand in California, such as herbaceous crops and the bulk of corn ethanol (see Tables S34 and S35). Emissions for each biofuel refinery were estimated using CA-GREET1.8b emissions rates per unit of fuel produced.

\subsubsection{Biogas capture and use}

CA-TIMES assumes that landfill gas reduces over time due to better management of organic matter in landfills and the consumption of existing landfill stock material over many decades. All biogas in CA-TIMES is converted to biomethane through removal of $\mathrm{CO}_{2}$ and impurities and further blended with natural gas so that it is undistinguishable from extracted fossil natural gas.

Dairy biogas is a significant renewable energy source in CA-TIMES. California produced a fifth of the milk in the US in 2010 (California Department of Food and Agriculture, 2011) and an exponential regression using 2001-2013 CFDA data estimates the number of dairy cows in California may increase by a factor of 1.5 by the year 2050 . Methane emissions rates were estimated from GHG inventory documentation (California Air Resources Board, 2014) for each manure management practice: liquid/slurry, anaerobic lagoon, anaerobic digester, daily spread, deep pit, pasture, and solid storage. The increase in the cow population was assumed to occur uniformly across all management practices except for the systems used in biogas capture. These systems, including anaerobic digester, anaerobic lagoon, and liquid/slurry management practices, were adjusted to meet the quantities of biogas specified by each CA-TIMES scenario. The amount of waste produced by each dairy cow each year was used to estimate the annual biomethane production and energy potential of each animal. The electricity potential from biomethane is then calculated using AgSTAR conversion rates (Environmental Protection Agency, 2010; US Environmental Protection Agency AgSTAR Program, 2011). The overall fugitive VOC emissions from animal waste declines in the biogas production scenarios since a large fraction of the waste is treated. Overall, fugitive dairy manure VOC emissions increased by $50 \%$ due to cow population growth in the BAU scenario and decreased by $33 \%$ for the GHG-Step scenario relative to 2010 .

Future biomethane production sites were selected based on recommendations from the USDA's Cooperative Approaches for Implementation of Dairy Manure Digesters (US Department of Agriculture Rural Development Agency, 2009). Mainly, locations were selected with nearby pipeline networks (Gilbreath et al., 2014) to transport raw biogas to a centralized cleanup facility, where it can then be compressed and sold for use by electric generation power plants or as transportation fuels. This was considered a more viable option as natural gas pipeline infrastructure is easy to access, demand from electric utilities for biomethane is high to meet the renewable portfolio standard, and a centralized cleanup facility is more economical than distributed facilities. 
Table 4. Pollutant emissions rate associated with hydrogen production. Units are micrograms of pollutant per kilojoule of hydrogen produced.

\begin{tabular}{lccc}
\hline & $\begin{array}{c}\text { SMR - average of } \\
\text { top CA H } \\
\text { facilities }\end{array}$ & $\begin{array}{c}\text { Gasification }- \text { CA- } \\
\text { GREET 2015 gasification } \\
\text { vs. SMR scaling }\end{array}$ & Electrolysis \\
\hline $\mathrm{CO}$ & 4.079 & 0.997 & 0 \\
$\mathrm{NO}_{x}$ & 1.612 & 0.34 & 0 \\
$\mathrm{SO}_{x}$ & 0.087 & 0.406 & 0 \\
$\mathrm{VOC}$ & 2.208 & 1.118 & 0 \\
$\mathrm{PM}_{10}$ & 0.410 & 0.048 & 0 \\
\hline
\end{tabular}

\section{Results and discussion}

\subsection{On-road mobile emissions}

Figure 11 illustrates PM emissions of tire and brake wear from on-road vehicles under the BAU and GHG-Step scenarios. The fine spatial distribution of the emissions reflects the spatial distribution of tire- and brake-wear emissions in the base 2010 inventory that is updated using EMFAC predictions to produce the intermediate 2050 emissions inventory. The technology changes inherent in the CA-TIMES BAU and GHG-Step scenarios are then applied uniformly across the state, yielding virtually identical spatial distributions for the final 2050 BAU and GHG-Step scenario emissions. Tire- and brake-wear emissions patterns illustrated in Fig. 11 essentially follow predicted vehicle activity patterns in the state. Predicted emissions are highest in major urban centers and along major transportation corridors. Although increase in vehicular activity was part of this study, expansion of roadways between 2010 and 2050 was not considered in this study and may be updated in newer versions of the model.

California's environmental regulations apply uniformly across the state, which supports the assumption of uniform GHG emissions reductions for on-road vehicles. Despite the uniform regulatory landscape, some of the measures described in the CA-TIMES GHG-Step scenario rely on modified behavioral patterns and willingness or ability to adopt new technologies, which may change by region. Education levels, personal wealth, and environmental attitudes vary sharply across California. Capturing these trends in subregions of the state will require surveys of consumer choice and predictions of future behavior that are beyond the scope of the current paper.

Figure 12 illustrates the PM emissions from tailpipe exhaust under the 2050 BAU scenario and the 2050 GHG-Step scenario. Similar to the tire- and brake-wear emissions, the spatial pattern for mobile sources is identical under both scenarios because the technology changes specified by the CATIMES model are applied uniformly over the entire state. Tailpipe PM emissions once again follow patterns of vehicle activity as predicted by EMFAC. Of greater interest is the prediction that tire- and brake-wear emissions (Fig. 11) will exceed tailpipe emissions (Fig. 12) in both the 2050 BAU and GHG-Step scenarios due to the adoption of increasingly clean vehicle technology. Tailpipe emissions in the GHGStep scenario are a factor of $\sim 1.8$ lower than tailpipe emissions in the BAU scenario. In contrast, tire- and brake-wear emissions are predicted to decrease by a factor of +3 under the GHG-Step scenario. This reflects the fact that BAU gasoline and diesel tailpipe emissions already incorporate significant emissions control technology yielding fewer opportunities for further improvement. Tire- and brake-wear emissions have almost no control technology in the BAU scenario, which makes the widespread adoption of electric or hybrid drivetrains using regenerative braking particularly effective at reducing emissions.

The current analysis assumes that no new major highways will be built in California and population growth is accommodated partially through increased urban density such that traffic volumes increase uniformly across the transportation network. These assumptions are simplistic but a previous study of smart growth in the San Joaquin Valley indicated that more detailed accounting of population growth had minimal impact on air quality (Hixson et al., 2010).

\subsection{Rail and off-road emissions}

PM emissions from off-road and rail sources are plotted in Fig. 13 for the BAU and GHG-Step scenarios examined in the current study. Maximum statewide PM emissions for this source category are centered at the location of major construction projects with lower emissions rates for "routine" off-road emissions distributed more broadly according to typical activity patterns for smaller construction projects, rail, etc. The 2010 emissions inventory that acts as the basis for the 2050 projections in the current project correctly identified replacement of the east span of the Bay Bridge in the San Francisco Bay Area as the leading construction project with the highest overall emissions in the state. This $\sim$ USD 6.5 billion project spanned more than 10 years, with the new bridge completed in 2013 and final decommissioning and demolition of the old eastern span scheduled for 2018.

It is difficult to predict the location of major construction projects in 2050 but it is reasonable to expect that several large projects will be active in that timeframe. Candi- 
(a) $2050 \mathrm{BAU}\left(\mu \mathrm{g}^{-2} \mathrm{~m} \mathrm{~min}^{-1}\right)$

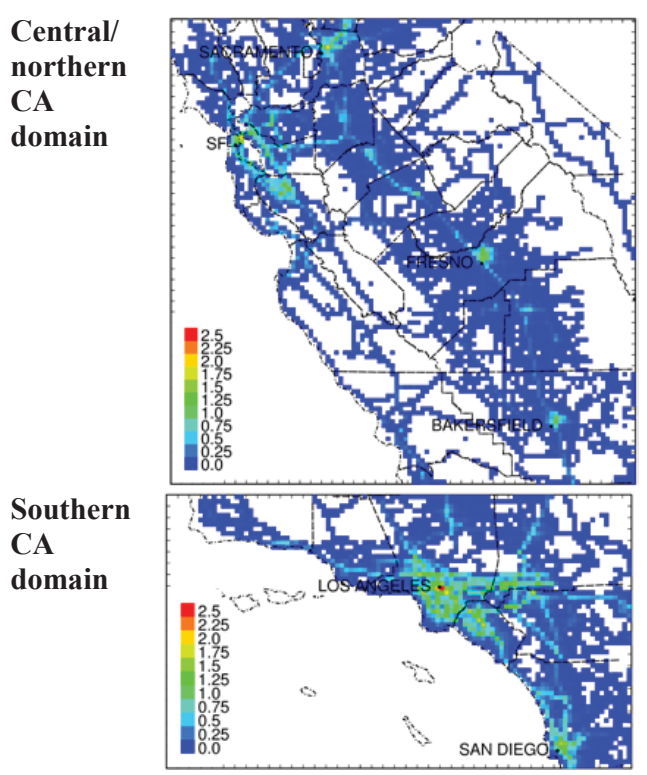

(b) 2050 GHG-step minus BAU $\left(\mu \mathrm{g} \mathrm{m}^{-2} \min ^{-1}\right)$

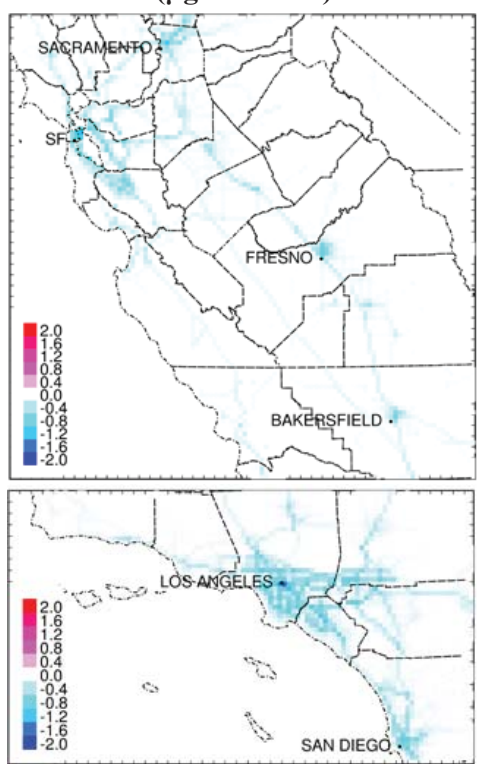

Figure 11. Particulate matter emissions from vehicle tire and break wear in the BAU scenario (a) and emissions change in the GHG-Step scenario (b). Units are $\mu \mathrm{g} \mathrm{m}^{-2} \mathrm{~min}^{-1}$.

(a) $2050 \mathrm{BAU}\left(\mu \mathrm{g}^{-2} \mathrm{~m} \mathrm{~min}^{-1}\right)$

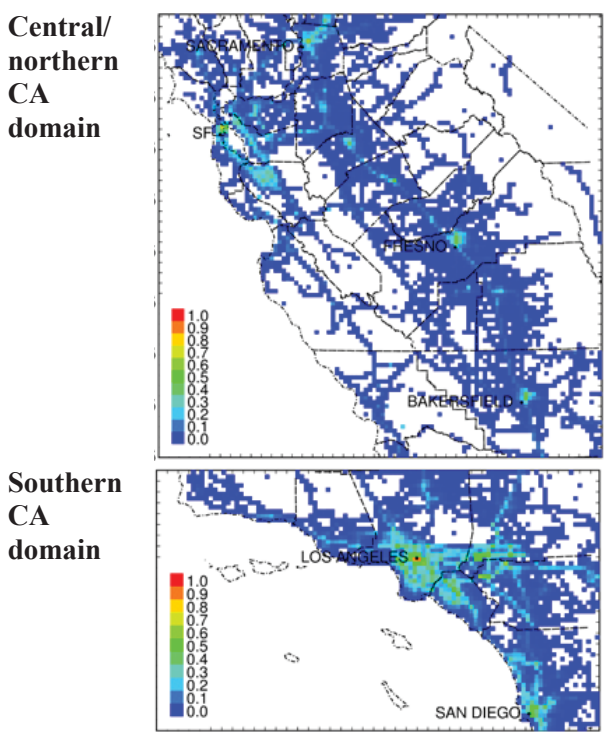

(b) 2050 GHG-step minus BAU $\left(\mu \mathrm{m}^{-2} \min ^{-1}\right)$

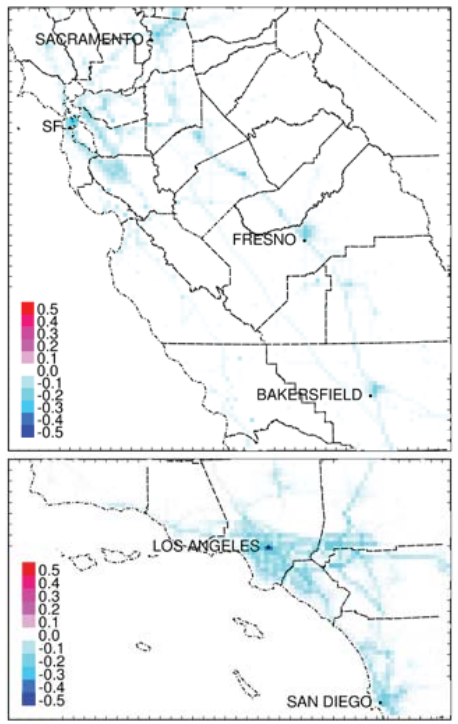

Figure 12. Particulate matter emissions of vehicle tailpipe exhaust in the BAU scenario (a) and emissions change in the GHG-Step scenario (b). Units are $\mu \mathrm{g} \mathrm{m}^{-2} \mathrm{~min}^{-1}$.

date projects currently under discussion include additional replacement of California's numerous highways and bridges, upgrading California's water conveyance systems to better withstand earthquakes, development of high-speed rail lines, reinforcement or expansion of seawalls to protect property, etc. Each of these projects will potentially emit criteria pollu- tants that would affect air quality over major urban centers. In the present study, the peak emissions associated with the major construction project around the Bay Bridge were retained in the future scenario as an example of a major construction project near an urban area. Future model analysis that uses these emissions should conduct sensitivity tests to en- 
(a) $2050 \mathrm{BAU}\left(\mu \mathrm{g}^{-2} \mathrm{~m} \mathrm{~min}^{-1}\right)$

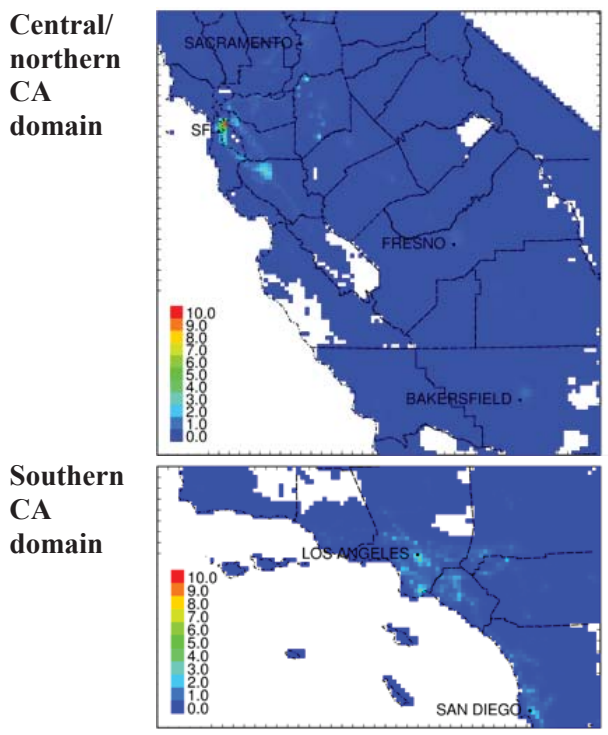

(b) 2050 GHG-step minus BAU

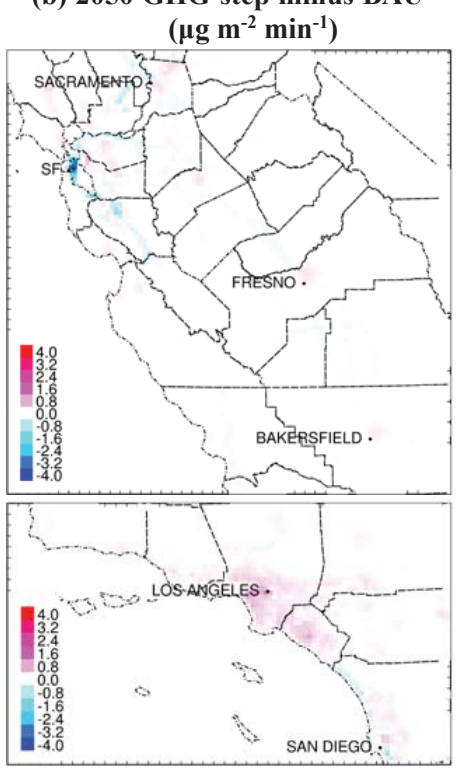

Figure 13. Particulate matter emissions from rail and other off-road sources in the BAU scenario (a) and emissions change in the GHG-Step scenario (b). Units are $\mu \mathrm{g} \mathrm{m}^{-2} \mathrm{~min}^{-1}$.

sure that the assumed placement of this example major construction project does not influence the overall conclusions of the study.

Maximum PM emissions shown in Fig. 13 decrease by a factor of approximately 1.64 in the GHG-Step scenario relative to the BAU scenario. Adoption of biomass-based fuels was also found to reduce emissions of $\mathrm{SO}_{x}, \mathrm{HC}, \mathrm{PM}$, and occasionally $\mathrm{CO}$ from off-road and rail sources, but $\mathrm{NO}_{x}$ emissions increased for some fuel choices.

\subsection{Marine and aviation emissions}

PM emissions from marine and aviation sources are shown in Fig. 14 for the BAU and GHG-Step scenarios considered in the present study. The highest PM emissions rates occur in offshore shipping lanes that converge on the Port of Los Angeles, the Port of Long Beach, and the Port of Oakland. Emissions rates change with proximity to California shores due to regulations governing sulfur content of marine fuel or ship speed. Emissions patterns at inland locations reflect shipping activity on inland waterways or activity surrounding small regional airports.

Maximum PM emissions rates from marine sources increase under the GHG-Step scenario as illustrated most clearly in the right panels of Fig. 14. CA-TIMES determined that the available biofuel capacity could be more efficiently used to offset traditional fossil fuels for on-road transportation sources and so the GHG-Step scenario is predicted to incorporate additional fossil fuels for marine sources under the GHG-Step scenario vs. the BAU scenario. The net result of the disbenefits associated with increased marine emis- sions vs. the benefits of the decreased on-road emissions will be considered in future studies that include analysis with regional air quality models.

\subsection{Residential and commercial emissions}

Figure 15 illustrates PM emissions from residential and commercial sources under the 2050 BAU and GHG-Step scenarios. The spatial patterns of emissions largely follow the estimated population projections in California in the year 2050 as summarized in Table S24 in the Supplement. Population growth was assumed to be identical under the BAU and GHG-Step scenarios yielding virtually identical spatial distributions for both scenarios. The adoption of new technologies and altered behavioral patterns predicted by the CATIMES model under the GHG-Step scenario were applied uniformly over the state without modification by income, education level, or regional differences in environmental attitudes. Predicted changes to PM emissions from residential and commercial sources are modest with slight reductions of $\sim 10 \%$ mostly attributed to energy efficiency measures. Widespread adoption of biomethane to replace natural gas is predicted in the GHG-Step scenario but this fuel change has little impact on criteria pollutant emissions. 
(a) $2050 \mathrm{BAU}\left(\mu \mathrm{g}^{-2} \mathrm{~m} \mathrm{~min}^{-1}\right)$

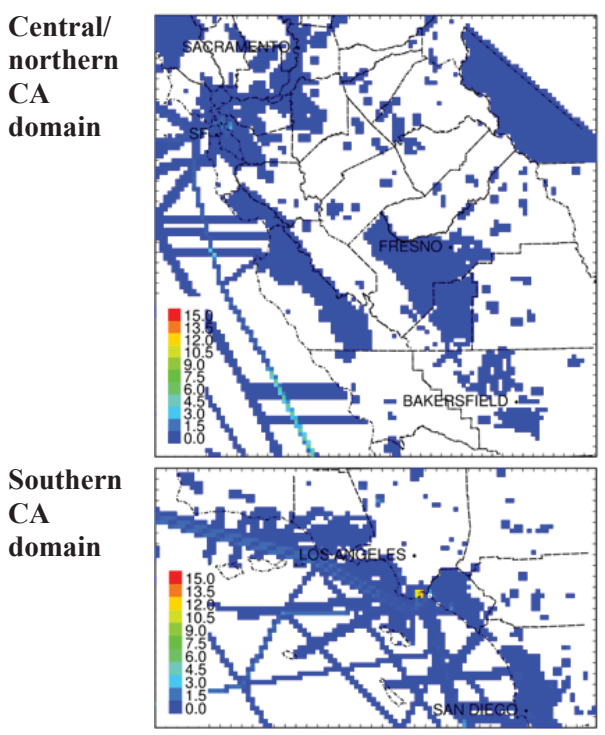

(b) 2050 GHG-step minus BAU

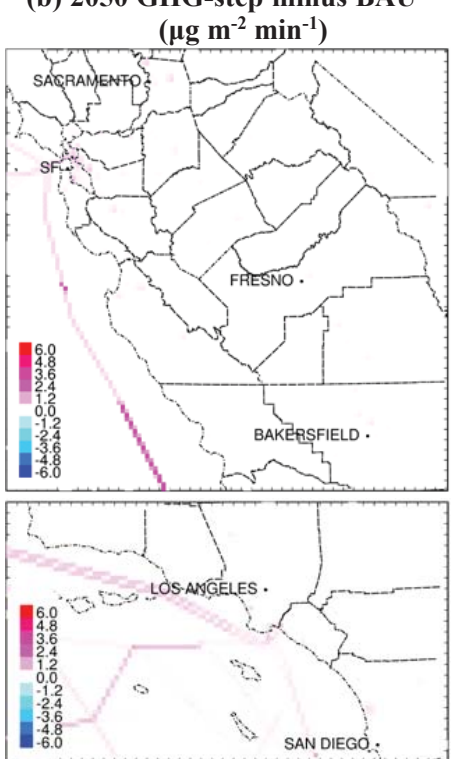

Figure 14. Particulate matter emissions from marine and aviation sources in the BAU scenario (a) and emissions change in the GHG-Step scenario (b). Units are $\mu \mathrm{g} \mathrm{m}^{-2} \mathrm{~min}^{-1}$.

(a) $2050 \mathrm{BAU}\left(\mu \mathrm{g}^{-2} \mathrm{~m} \mathrm{~min}^{-1}\right)$

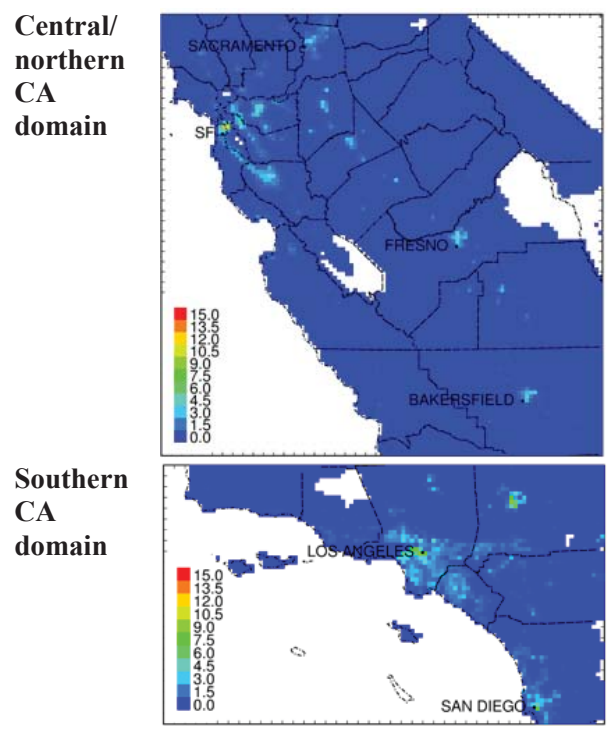

(b) 2050 GHG-step minus BAU

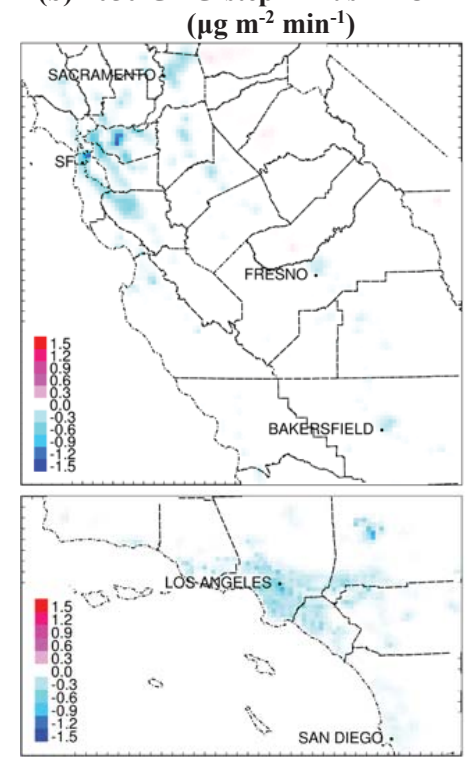

Figure 15. Particulate matter emissions from residential and commercial sources in the BAU scenario (a) and emissions change in the GHG-Step scenario (b). Units are $\mu \mathrm{g} \mathrm{m}^{-2} \mathrm{~min}^{-1}$.

\subsection{Electricity generation emissions}

Figure 16 illustrates predicted emissions of PM from combustion processes used to generate electricity. These emissions are represented as point sources and so only the grid cells containing an electrical generation unit are colored. The highest emissions rates for individual grid cells are associated with a small number of major electrical generation sta- tions typically powered by natural gas in the BAU scenario. The majority of the colored grid cells in Fig. 16 are associated with smaller backup generators that operate intermittently and therefore have very low emissions. These backup units are typically powered by a fossil fuel such as diesel fuel in the BAU scenario, with a shift to biofuels in the GHG-Step 
(a) $2050 \mathrm{BAU}\left(\mu \mathrm{g}^{-2} \mathrm{~m} \mathrm{~min}^{-1}\right)$

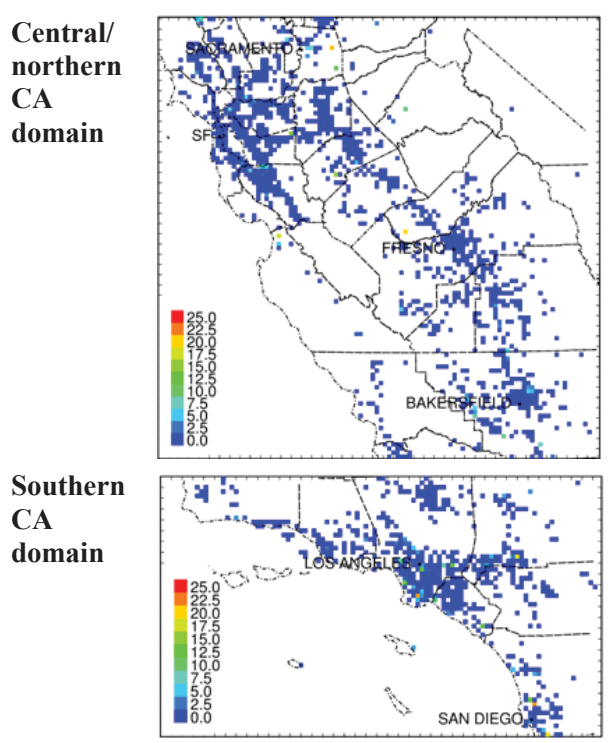

(b) 2050 GHG-step minus BAU $\left(\mu \mathrm{g} \mathrm{m}^{-2} \mathrm{~min}^{-1}\right)$

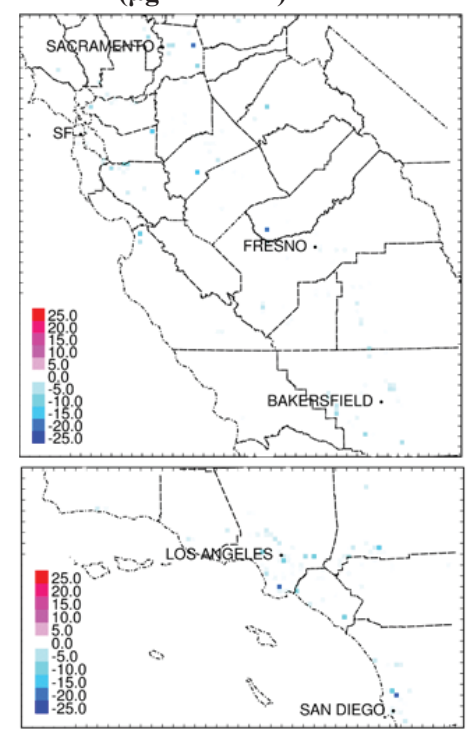

Figure 16. Particulate matter emissions from electricity generation (emissions source category type 6) in the BAU scenario (a) and emissions change in the GHG-Step scenario (b). Units are $\mu \mathrm{g} \mathrm{m}^{-2} \mathrm{~min}^{-1}$.

scenario. This fuel switch has a modest impact on total emissions given the low utilization of these units.

Peak emissions rates of PM decrease by a factor of $\sim 1.7$ in the GHG-Step scenario primarily due to a reduction in fossil fuel electricity generation in favor of a shift to solar and wind sources (see Fig. 10). All generating stations are assumed to continue operation at a reduced rate in the GHG-Step scenario rather than selectively decommissioning some stations. The age and efficiency of existing naturalgas-generating stations will likely be key factors determining how they are operated in the future scenarios. Solar and wind electricity generation does not emit criteria pollutants and so the location of these facilities is not shown in Fig. 16.

\subsection{Biorefinery emissions}

Figure 17 shows the locations of refineries producing biofuels (biorefineries) in California under the BAU and GHGStep scenarios considered in the present study. The location of future biorefineries was chosen to minimize transportation costs for the raw materials feeding into the refinery and the delivery of fuel to the final point of end use. Additional zoning constraints were considered to prevent the placement of biorefineries near schools, hospitals, or other locations with sensitive populations. More generally, a constraint was considered to restrict the placement of new biorefineries in regions that currently violate the NAAQS. The top panels of Fig. 11 therefore do not allow the placement of biorefineries in either the San Joaquin Valley or the South Coast Air Basin (SoCAB), while the less constrained scenarios illustrated in the lower panels of Fig. 17 do not impose this restriction. In practice, biorefineries were generally sited near landfills or industrial or agricultural areas within each city selected as economically optimal within the specified constraints. The enforcement of NAAQS constraints on biorefineries led to a smaller number of larger refineries under both the BAU and GHG-Step scenarios. Note that overall biorefining output is higher in the BAU scenario than in the GHG-Step scenario. Biofuels have lower associated GHG emissions than traditional fossil fuels but their carbon intensity is still too high to meet the GHG emissions target represented in the GHGStep scenario. The CA-TIMES model therefore predicts that a portion of the energy supplied by biofuels in the BAU scenario will instead be supplied by wind and solar in the GHGStep scenario.

\subsection{Summary of statewide emissions}

Figure 18a illustrates the net change in emissions related to criteria pollutants in California in the GHG-Step scenario vs. the BAU scenario analyzed in the current study. Emissions of each pollutant are broken down by the major emissions categories analyzed in Sect. 2. The miscellaneous category is equivalent in the BAU and GHG-Step scenarios and hence is not plotted. Contributions below $0 \%$ indicate emissions reductions, while contributions above $0 \%$ indicate emissions increases. Each of these changes represents the statewide average for the sources within the indicated sector. Note that the changes within each sector may not be uniform across the entire state. The net change in total emissions is indicated by the black horizontal line for each species. It is immediately apparent that the emissions reductions illustrated 


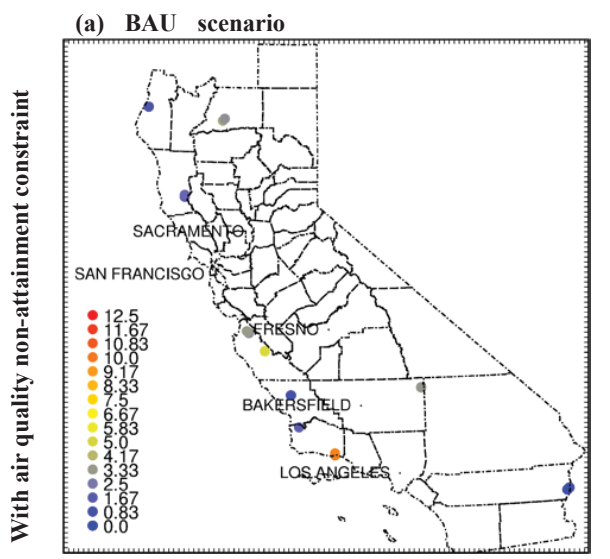

(b) GHG-step scenario
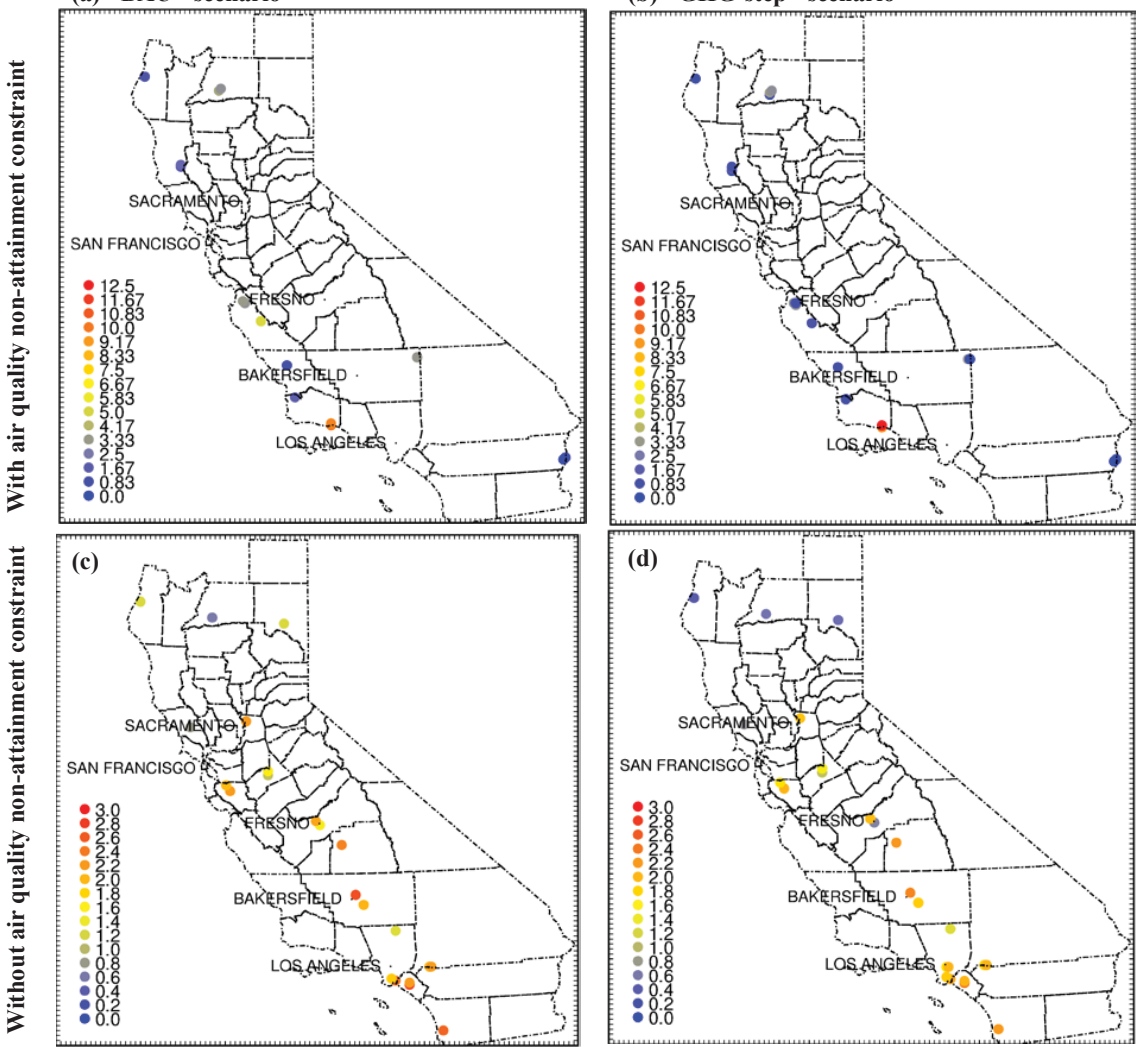

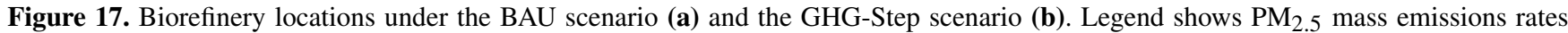
per facility $\left(\mu \mathrm{g} \mathrm{m}^{-2} \mathrm{~min}^{-1}\right.$ ). Panels (a) and (b) represent the constrained case in which biorefineries cannot be located in air basins out of compliance with National Ambient Air Quality Standards (NAAQS). Panels (c) and (d) are not constrained by NAAQS status.

in Fig. 18a are not uniform for all pollutants. Maximum reductions of $\sim 60 \%$ are observed for $\mathrm{CO}_{2}$ and particulate copper $(\mathrm{Cu})$ emissions. In contrast, emissions of particulate $\mathrm{SO}_{4}^{2-}$, gaseous $\mathrm{CO}$, and gaseous $\mathrm{SO}_{x}$ actually increase under the GHG-Step scenario due to trade-offs in the technologies adopted in the off-road mobile categories (rail, marine, aviation, etc.) needed to optimize the overall GHG emissions across the state. Emissions of pollutants that experience increasing trends in Fig. 18a are minor in the present-day inventory and so they do not currently trigger NAAQS violations. Changes in key highly emitted pollutants fall in between the extreme cases described above (see results for particulate elemental carbon (EC), particulate OC, and gaseous $\mathrm{NO}_{x}$ ). Each of these pollutants experiences a net decrease in total emissions averaged across California, but emissions changes are not uniform across all categories. Some technology and fuel changes cause higher emissions, which are offset by savings in other categories. This complex mixture of trade-offs reflects the optimal economic approach to GHG reductions determined by the CA-TIMES model.

The changing activity patterns, fuels, and technologies included in the GHG-Step scenario lead to changes in the emitted particle size and composition distribution. This leads to differences in the response of primary PM with aerodynamic diameter less than $2.5 \mu \mathrm{m}\left(\mathrm{PM}_{2.5}\right)$ and less than $0.1 \mu \mathrm{m}$ $\left(\mathrm{PM}_{0.1}\right.$; ultrafine particles). Ultrafine particles are an emerging pollutant of concern expected to influence public health (Delfino et al., 2005; Hoek et al., 2010; Knol et al., 2009). The results shown in Fig. 18a illustrate that the GHG-Step scenario leads to only a $4 \%$ decrease in primary $\mathrm{PM}_{2.5}$ emissions but a much larger $36 \%$ reduction in $\mathrm{PM}_{0.1}$ emissions. Recent epidemiology results indicate that $\mathrm{PM}_{0.1}$ is associated with mortality in the California Teachers Study (Ostro et al., 2015). Likewise, toxicology studies indicate that ultrafine particles are more toxic than larger particles per unit mass (Donaldson et al., 2001, 2002; Elder et al., 2006; Kreyling et al., 2004; Oberdorster et al., 2002). Enhanced $\mathrm{PM}_{0.1}$ emissions reductions could amplify the potential health benefits of the future GHG-Step scenario beyond the level expected from $\mathrm{PM}_{2.5}$ emissions reductions.

Figure 18b shows the net change in criteria pollutant emissions predicted using the expert analysis approach described by Shindell et al. (2012). These results are presented as a comparison point to the results illustrated in Fig. 18a and listed in Tables S36 through S38 in the Supplement. The expert analysis scenario focused on a small number of measures 


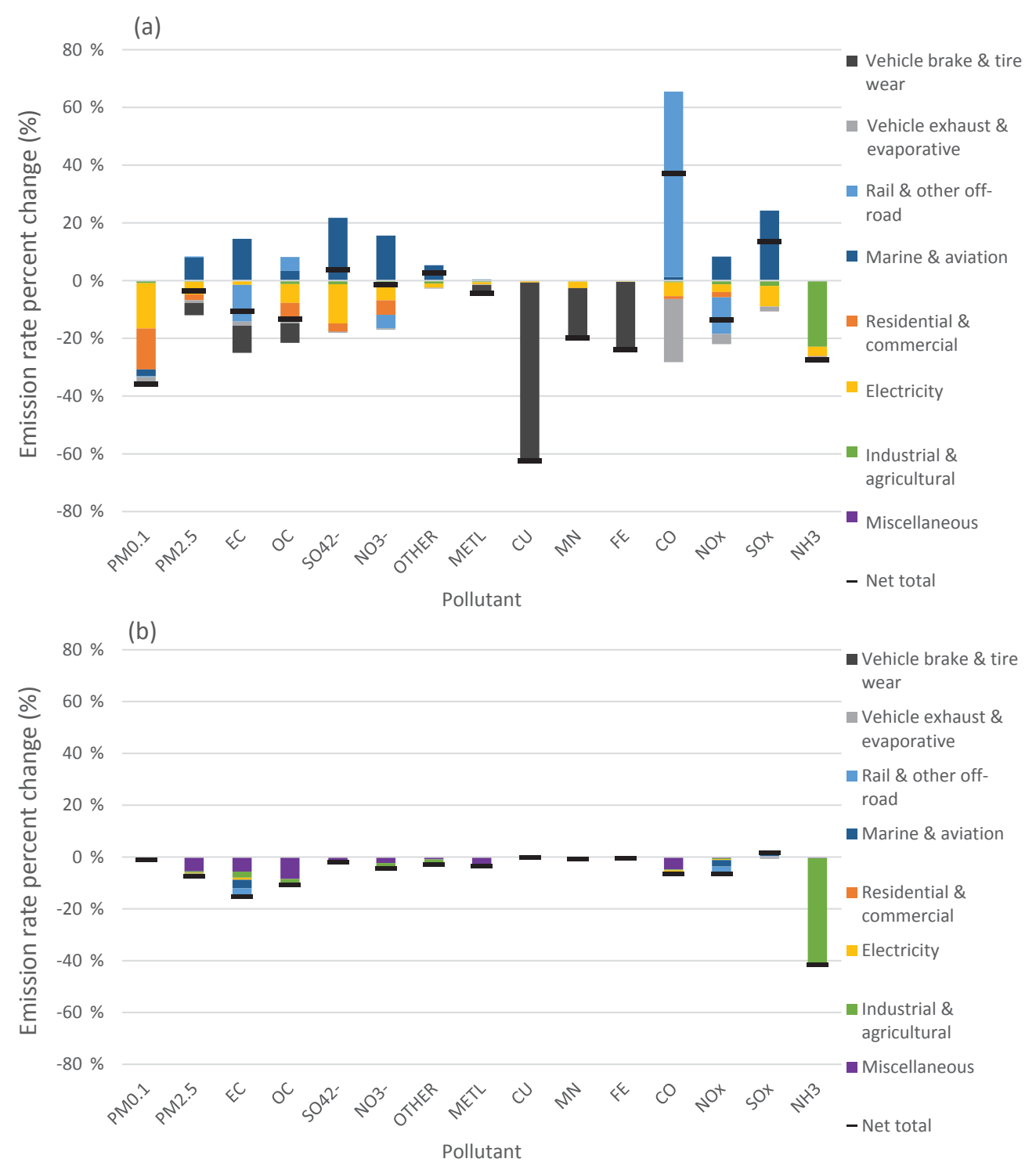

Figure 18. Change in pollutant emissions rate relative to BAU scenario. Panel (a) represents GHG-Step analyzed in the current study using the CA-TIMES model. Panel (b) represents expert analysis presented by Shindell et al. (2012).

targeted for countries which are in the early stages of adopting policies to reduce GHG emissions or mitigate regional air quality problems. As a result, the measures described by Shindell et al. have a large impact on global public health but they will have a very minor impact on California (or any other major state or country that has already implemented significant emissions controls).

Comparison of Fig. 18a and b illustrates that only reductions in particulate EC are comparable in the Shindell et al. and CA-TIMES scenarios due to the mitigation of emissions from off-road diesel engines. CA-TIMES accomplishes this reduction through a combined switch in fuels and adoption of diesel particle filters on remaining diesel and biodiesel sources to achieve a combined reduction in GHG emissions and criteria pollutant emissions. Shindell et al. assume uniform adoption of diesel particle filters on all off-road diesel engines with no fuel switching. Shindell et al. also specify the adoption of digesters for dairy waste and increased use of landfill gas as renewable methane sources. CA-TIMES predicts similar adoption resulting in a $\sim 35-40 \%$ reduction in ammonia $\left(\mathrm{NH}_{3}\right)$ emissions from these sources. The CATIMES approach considered in the present study additionally considers how the emissions of biomethane differ from the emissions of traditional natural gas. The only other significant measure specified by Shindell et al. that could reduce criteria pollutant emissions in California is a complete ban on burning of agricultural waste. California already limits agriculture burns to avoid stagnation periods. Thus, even the 

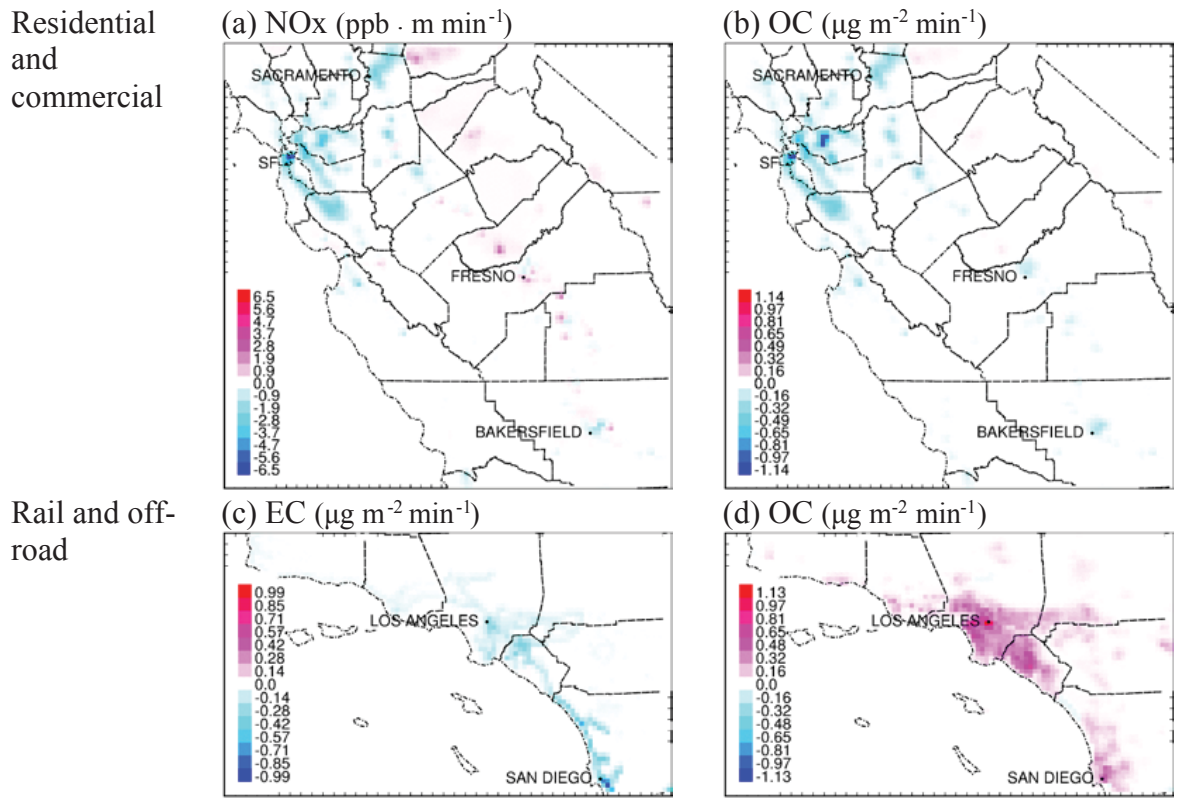

(d) $\mathrm{OC}\left(\mu \mathrm{g} \mathrm{m} \mathrm{min}^{-1}\right)$

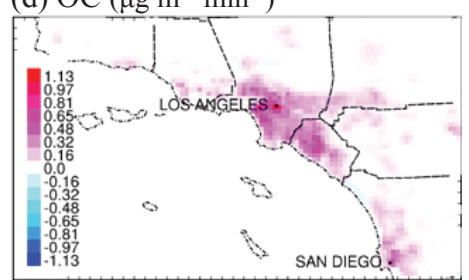

Figure 19. Change in emissions in the GHG-Step scenario relative to the BAU scenario. (a) $\mathrm{NO}_{x}$ from residential and commercial sources $\left(\mathrm{ppb} \mathrm{mm^{-1 }}\right)$, (b) particulate OC from residential and commercial sources $\left(\mu \mathrm{g} \mathrm{m}^{-2} \mathrm{~min}^{-1}\right)$, (c) particulate EC from off-road and rail sources $\left(\mu \mathrm{g} \mathrm{m}^{-2} \mathrm{~min}^{-1}\right)$, and (d) particulate OC from off-road and rail sources $\left(\mu \mathrm{g} \mathrm{m}^{-2} \mathrm{~min}^{-1}\right)$.

apparent savings associated with reduced agricultural burns shown in Fig. $18 \mathrm{~b}$ are likely to have limited practical impact on air quality in the state. Shindell et al. do not consider the adoption of low-carbon fuels or electrification of on-road vehicles, which are necessary to achieve deep GHG reductions in CA.

Overall, the analysis presented by Shindell et al. (2012) is appropriately targeted at global health but the measures considered in this analysis do not achieve California's GHG objectives and the criteria pollutant emissions changes associated with them will not support calculations for future air quality in California. Energy economic models such as CATIMES represent a more realistic tool for development of scenarios in regions like California that have already considered all simple measures. Careful analysis is required to understand the resulting complex pattern of trade-offs between emissions in different categories that result from these scenarios.

Figure 19 illustrates examples of spatial patterns of emissions changes under the GHG-Step scenario predicted by CA-TIMES in the current study. The offsetting increasing and decreasing emissions changes illustrated in Fig. 18 do not occur uniformly over the state but instead appear as regions of localized increasing and decreasing emissions. As an even greater complication, the spatial pattern of increasing and decreasing emissions changes for each pollutant. The top panels of Fig. 19 illustrate changes in the commercial and residential sector for $\mathrm{NO}_{x}$ emissions (Fig. 19a) and OC emissions (Fig. 19b) in central California. Patterns of emis- sions increases or decreases are similar in major urban centers (San Francisco and Sacramento) but different patterns are predicted for emissions of $\mathrm{NO}_{x}$ and $\mathrm{OC}$ in the heavily polluted San Joaquin Valley (Fresno and Bakersfield). The lower panels of Fig. 19 illustrate even stronger variation in the spatial pattern of emissions changes in the off-road and rail categories in southern California. The spatial pattern of the change in particulate EC emissions (Fig. 19c) differs strongly from the spatial pattern of the change in particulate OC emissions (Fig. 19d)

All of the emissions illustrated in Fig. 19 will produce regions of increased or decreased pollutant concentrations. Given that each region is highly populated, these emissions patterns will have a direct effect on population exposure. Detailed analysis with regional air quality models at a resolution of $4 \mathrm{~km}$ or finer will be required to understand the health implications of these changing emissions. California requires this level of fine-scale emissions analysis to accurately predict the air quality impacts of future GHG mitigation strategies in the state. Similar efforts will be required to analyze the effects of GHG mitigation strategies on criteria pollutants in other highly populated regions that have already moved beyond simple emissions regulations banning obvious sources of air pollution.

The CA-REMARQUE projections for criteria pollutant emissions associated with optimal climate policies in California should not be directly extrapolated to other regions or countries. Instead, the methods used by CA-REMARQUE should be applied to each new region to fully consider the ap- 
propriate energy resources available, consumption patterns, equipment vintages, aftertreatment regulations, and population and economic growth rates. Each region may have a different optimal set of GHG mitigation technologies and policies that will lead to different rates and spatial patterns of emissions compared to the changes predicted in California. Many developing regions will be able to select less expensive GHG mitigation strategies that also reduce GHG and criteria pollutant emissions relative to their BAU scenario. Within developed regions such as other US states, the elements of the mobile emissions inventory maintained by the US EPA (MOVES and mobile portion of the National Emissions Inventory) can be adapted to replace the corresponding California information (EMFAC, mobile portion of the CARB inventory). Changes to off-road emissions would need to be estimated following procedures similar to those employed in the CARB off-road VISION model. Effort would be needed to estimate how changes to marine fuel sources would influence emissions at major ports. Studies would need to be conducted describing potential locations for new facilities producing low-carbon fuels and the resulting emissions from those facilities. This information would support a fully resolved analysis of the criteria pollutant emissions associated with climate policies outside of California.

\section{Conclusions}

The California Regional Multisector Air Quality Emissions (CA-REMARQUE) model has been developed to translate optimized GHG mitigation policies into criteria pollutant emissions in California. Minimum-cost GHG policies are first selected by the energy economic model CA-TIMES. Tailored methods are then used to predict corresponding changes in criteria-pollutant emissions for individual categories including on-road vehicles, off-road vehicles, marine, aviation, rail, residential, commercial, electricity generation, industrial, and agricultural emissions. Translation methods account for efficiency improvements, changing technology, and changing fuels with corresponding changes to criteria pollutant emissions. Modifications to the composition of reactive organic gases and the size and composition of airborne PM are considered. Translation methods also account for increased emissions associated with some measures, such as the need to produce new biofuels including biodiesel, ethanol, and hydrogen.

The CA-REMARQUE model is demonstrated by predicting emissions in 2050 under a business-as-usual (BAU) scenario and an optimized GHG mitigation scenario (GHGStep) in California. The results show that the optimal scenario for GHG mitigation produces increasing criteria pollutant emissions in some categories that are offset by decreases in other categories. These trade-offs yield a complex pattern of emissions trends with subregions of increasing emissions and subregions of decreasing criteria pollutant emissions across California when viewed at $4 \mathrm{~km}$ spatial resolution. In contrast, a simplified expert analysis scenario designed to address global GHG emissions may not necessarily reduce criteria pollutant emissions in California because many emissions sources have already been controlled by the state's air pollution regulations. The expert analysis method does not consider complex fuel, switching scenarios beyond the replacement of natural gas with biomethane. Choosing an economically optimal scenario of additional measures needed to achieve GHG mitigation goals in California requires tools beyond expert analysis opinions. Likewise, fully accounting for the corresponding changes to criteria pollutant emissions requires sophisticated analysis in fully developed countries and states with strict existing environmental regulations.

The California subregions of increasing and decreasing criteria pollutant emissions predicted in the current project occur in close proximity to major population centers and so they will almost certainly influence population exposure and public health. The emissions inventories created in the current study will be analyzed using regional air quality models in a future study to fully calculate impacts on public health.

Code and data availability. CA-REMARQUE was developed and executed in the Linux programming environment using standard shell scripts and FORTRAN programs compiled using the Portland Group software. All of the data necessary to calculate changes to emissions inventories are published in full in the main text and supporting information section of the paper. The output emissions datasets are available free of charge at faculty.engineering.ucdavis. edu/kleeman/. The program code is currently being updated to use the latest version of the California EMFAC software and will be posted at faculty.engineering.ucdavis.edu/kleeman/ when complete. Note that the CA-REMARQUE v1.0 model is separate from the CA-TIMES energy-economic model and the California EMFAC model.

\section{The Supplement related to this article is available online at https://doi.org/10.5194/gmd-11-1293-2018- supplement.}

Acknowledgements. This study was funded by a National Center for Sustainable Transportation Dissertation Grant and the United States Environmental Protection Agency under grant no. R83587901. Although the research described in the article has been funded by the United States Environmental Protection Agency it has not been subject to the Agency's required peer and policy review and therefore does not necessarily reflect the reviews of the agency and no official endorsement should be inferred.

Edited by: Tim Butler

Reviewed by: two anonymous referees 


\section{References}

Alleman, T. L., Eudy, L., Miyasato, M., Oshinuga, A., Allison, S., Corcoran, T., Chatterjee, S., Jacobs, T., Cherrillo, R. A., Clark, R., Virrels, I., Nine, R., Wayne, S., and Lansing, R.: Fuel Property, Emission Test, and Operability Results from a Fleet of Class 6 Vehicles Operating on Gas-To-Liquid Fuel and Catalyzed Diesel Particle Filters, SAE Technical Paper 2004-012959, https://doi.org/10.4271/2004-01-2959, 2004.

Alleman, T. L., Barnitt, R., Eudy, L., Miyasato, M., Oshinuga, A., Corcoran, T., Chatterjee, S., Jacobs, T., Cherrillo, R. A., Clark, N., and Wayne, W. S.: Final Operability and Chassis Emissions Results from a Fleet of Class 6 Trucks Operating on Gas-toLiquid Fuel and Catalyzed Diesel Particle Filters, SAE Technical Paper 2005-01-3769, https://doi.org/10.4271/2005-01-3769, 2005.

Antanaitis, D. B.: Effect of Regenerative Braking on Foundation Brake Performance, SAE Int. J. Passeng. Cars - Mech. Syst., 3, 14-30, 2010.

Argonne National Laboratory Transportation Technology R\&D Center: The VISION Model, available at: http://www.anl.gov/ energy-systems/project/vision-model (last access: April 2013), 2012.

Argonne National Laboratory Transportation Technology R\&D Center: GREET Model. The Greenhouse Gases, Regulated Emissions, and Energy Use in Transportation Model, available at: https://greet.es.anl.gov/ (last access:d June 2015), 2014.

Bollen, J., van der Zwaan, B., Brink, C., and Eerens, H.: Local air pollution and global climate change: A combined cost-benefit analysis, Resour. Energy Econ., 31, 161-181, 2009.

California Air Resouces Board: Documentation of California's 2000-2012 GHG Inventory, 2014.

California Air Resources Board: Final Regulation Order - Amendments to Sects. 1900 and 1961 and Adoption of New Sects. 1961.1, Title 13, California Code of Regulations as Approved by OAL and filed with the Secretary of the State on 15 September 2005, California Air Resources Board, Sacramento, CA, 2005.

California Air Resources Board: Updated Informative Digest: Adoption of the Regulation to Reduce Emissions from Diesel Auxiliary Engines on Ocean-going Vessels while at Berth, California Air Resources Board, Sacramento, CA, 2007.

California Air Resources Board: CA-GREET version 1.8b, California Air Resources Board, Sacramento, CA, 2009a.

California Air Resources Board: Executive Order R-10-002. Relating to the Adoption of the Amendments to New Passenger Motor Vehicle Greenhouse Gas Emission Standards, California Air Resources Board, Sacramento, CA, 2009b.

California Air Resources Board: Final Regulation Order Amendments to the Low Carbon Fuel Standard Regulation. Adopt Sects. 95480.2, 95480.3, 95480.4, and 95480.5; Amend Sects. 95480.1, 95481, 95482, 95484, 95485, 95486, 95488, and 95490, title 17, California Code of Regulations, California Air Resources Board, Sacramento, CA, 2009c.

California Air Resources Board: Exhaust Emission Standards for Compression Ignition (Diesel) Engines and Equipment, Off-Road Compression-Ignition (Diesel) Engine Standards $\left(\mathrm{NMHC}+\mathrm{NO}_{x} / \mathrm{CO} / \mathrm{PM}\right.$ in $\left.\mathrm{gkWh}\right)$, California Air Resources Board, Sacramento, CA, 2010a.
California Air Resources Board: Final Regulation Order - Amendments to Title 13, California Code of Regulations. Rulemaking to Consider Proposed Amendments to New Passenger Motor Vehicle Greenhouse Gas Emission Standards for Model Years 2012-2016 to Permit Compliance based on Federal Greenhouse Gas Emission Standards, California Air Resources Board, Sacramento, CA, 2010b.

California Air Resources Board: Staff Report: Initial Statment of Reasons for Proposed Rulemaking. Regulation for Energy Efficiency and Co-Benefits Assessment of Large Industrial Facilities, in: Stationary Source Division Emissions Assessment Branch (Ed.), California Air Resources Board, Sacramento, CA, 2010c.

California Air Resources Board: EMFAC2011 Technical Documentation, California Air Resources Board, Sacramento, CA, 2011a.

California Air Resources Board: Facility Search Engine Tool. California Environmental Protection Agency Air Rersources Board, p. Find criteria and toxics pollutant emissions data for facilities in California, California Air Resources Board, Sacramento, CA, 2011 b.

California Air Resources Board: Final Regulation Order Adopt Sects. 95480.2, 95480.3, 95480.4, and 95480.5; Amend Sects. 95480.1, 95481, 95482, 95484, 95485, 95486, 95488, and 95490, title 17, California Code of Regulations, California Air Resources Board, Sacramento, CA, 2011c.

California Air Resources Board: Final Regulation Order - Subchapter 10 Climate Change, Article 5, Sects. 95800 to 96023, Title 17, California Code of Regulations, California Air Resources Board, Sacramento, CA, 2011d.

California Air Resources Board: Final Regulation Order. Fuel Sulfur and Other Operational Requirements for Ocean-going Vessels within California Waters and 24 Nautical Miles of the California Baseline, in: California Air Resources Board (Ed.), 13 CCR, Sect. 2299.2, California Air Resources Board, Sacramento, CA, 2011e.

California Air Resources Board: ARB Vision Model Documentation, Appendix to the June 27, 2012 Draft Vision for Clean Air: A Framework for Air Quality and Climate Planning, Sacramento, CA, 2012a.

California Air Resources Board: Final Regulation Order - Part 1: Final Regulation Order: Amend Sect. 1962.1, Title 13, California Code of Regulations. Zero-Emission Vehicle Standards for 2009 through 2017 Model Year Passenger Cars, Light-Duty Trucks and Medium-Duty Vehicles, California Air Resources Board, Sacramento, CA, 2012b.

California Air Resources Board: Final Regulation Order - Part 2: California Exhaust Emission Standards and Test Procedures for 2009 through 2017 Model Zero-Emission Vehicles and Hybrid Electric Vehicles, in the Passenger Car, Light-Duty Truck and Medium-Duty Vehicle Classes, Adopted 17 December 2008, as last amended 22 March 2012, California Air Resources Board, Sacramento, CA, 2012c.

California Air Resources Board: Final Regulation Order - Part 3: Final Regulation Order: Adopt 1962.2, Title 13, California Code of Regulations. Zero-emission Vehicle Standards for 2018 and Subsequent Model Year Passenger Cars, Light-duty Trucks, and Medium-Duty Vehicles, California Air Resources Board, Sacramento, CA, 2012d.

California Air Resources Board: Final Regulation Order - Part 4: California Exhaust Emission Standards and Test Procedures for 
2018 and Subsequent Model Zero-Emission Vehicles and Hybrid Electric Vehicles and Hybrid Electric Vehicles, in the Passenger Car, Light-Duty Truck and Medium-Duty Vehicle Classes, California Air Resources Board, Sacramento, CA, 2012e.

California Air Resources Board: Final Regulation Order - Part 5: Final Regulation Order: Amend 1962.3, Title 13, California Code of Regulations. Electric Vehicle Charging Requirements, California Air Resources Board, Sacramento, CA, 2012f.

California Air Resources Board: Energy Efficiency and Co-Benefits Assessment of Large Industrial Sources. Hydrogen Sector Public Report, California Air Resources Board, Sacramento, CA, 2014.

California Air Resources Board: CA-GREET 2.0 Model and Documentation, California Air Resources Board, Sacramento, CA, 2015.

California Air Resources Board: Final Regulation Order - California Cap on Greenhouse Gas Emissions and Market-based Compliance Mechanisms, California Air Resources Board, Sacramento, CA, 2017.

California Department of Food and Agriculture: California Dairy Statistics 2010, in: California Department of Food and Agriculture (Ed.), 1220 N Street, Sacramento, CA 95814, 2011.

Cheung, K. L., Polidori, A., Ntziachristos, L., Tzamkiozis, T., Samaras, Z., Cassee, F. R., Gerlofs, M., and Sioutas, C.: Chemical Characteristics and Oxidative Potential of Particulate Matter Emissions from Gasoline, Diesel, and Biodiesel Cars, Environ. Sci. Technol., 43, 6334-6340, 2009.

Cheung, K. L., Ntziachristos, L., Tzamkiozis, T., Schauer, J. J., Samaras, Z., Moore, K. F., and Sioutas, C.: Emissions of Particulate Trace Elements, Metals and Organic Species from Gasoline, Diesel, and Biodiesel Passenger Vehicles and Their Relation to Oxidative Potential, Aerosol Sci. Tech., 44, 500-513, 2010.

Cooper, E., Arioli, M., Carrigan, A., and Jain, U.: Exhaust Emissions of Transit Buses. Sustainable Urban transportation fuels and Vehicles, Working Paper, EMBARQ, EMBARQ Global, 10 G Street NE, Suite 800, Washington DC 20002, USA, 1(202)729-7600, 2012.

Delfino, R. J., Sioutas, C., and Malik, S.: Potential Role of Ultrafine Particles in Associations between Airborne Particle Mass and Cardiovascular Health, Environ. Health Persp., 113, 934946, 2005.

Donaldson, K., Stone, V., Clouter, A., Renwick, L., and MacNee, W.: Ultrafine particles, Occup. Environ. Med., 58, 211, https://doi.org/10.1136/oem.58.3.211, 2001.

Donaldson, K., Brown, D., Clouter, A., Duffin, R., MacNee, W., Renwick, L., Tran, L., and Stone, V.: The pulmonary toxicology of ultrafine particles, J. Aerosol. Med., 15, 213-220, 2002.

Durbin, T. D., Cocker, D. R., Sawant, A. A., Johnson, K., Miller, J. W., Holden, B. B., Helgeson, N. L., and Jack, J. A.: Regulated emissions from biodiesel fuels from on/off-road applications, Atmos. Environ., 41, 5647-5658, 2007.

Elder, A., Gelein, R., Silva, V., Feikert, T., Opanashuk, L., Carter, J., Potter, R., Maynard, A., Finkelstein, J., and Oberdorster, G.: Translocation of inhaled ultrafine manganese oxide particles to the central nervous system, Environ. Health Persp., 114, 11721178, 2006.

Environmental Protection Agency: Inventory of US Greenhouse Gas Emissions and Sinks: 1990-2008, in: Environmental Protection Agency (Ed.), Office of Atmospheric Programs (6207J),
1200 Pennsylvania Avenue, N. W. Washington, DC 20460 USA, 2010.

Ferreira da Silva, M., Vicente de Assuncao, J., de Fatima Andrade, M., and Pesquero, C. R.: Characterization of metal and trace element contents of particulate matter $\left(\mathrm{PM}_{10}\right)$ emitted by vehicles running on Brazilian fuels-hydrated ethanol and gasoline with $22 \%$ of anhydrous ethanol, J. Toxicol. Env. Heal. A, 73, 901-909, 2010.

Frank, B. P., Tang, S., Lanni, T., Grygas, J., Rideout, G., Meyer, N., and Beregszaszy, C.: The Effect of Fuel Type and Aftertreatment Method on Ultrafine Particle Emissions from a Heavy-Duty Diesel Engine, Aerosol Sci. Tech., 41, 1029-1039, 2007.

Fripp, M.: Switch: a planning tool for power systems with large shares of intermittent renewable energy, Environ. Sci. Technol., 46, 6371-6378, 2012.

Garcia-Menendez, F., Saari, R. K., Monier, E., and Selin, N. E.: US Air Quality and Health Benefits from Avoided Climate Change under Greenhouse Gas Mitigation, Environ. Sci. Technol., 49, 7580-7588, 2015.

Gautam, M.: Testing of Volatile and Nonvolatile Emissions from Advanced Technology Natural Gas Vehicles. Final Report. Center for Alternative Fuels, Engines \& Emissions West Virginia University, Prepared for John Collins State of California Air Resources Board, CARB Final Report for contract No. 07-430, Sacramento California, 2011.

Gilbreath, J., Rose, T., and Thong, F. F.: California Natural Gas Pipelines, in: Map of Major Natural Gas Pipelines in California (Ed.), California Energy Maps, California Energy Comission, Sacramento California, 2014.

Graboski, M. S., McCormick, R. L., Alleman, T. L., and Herring, A. M.: The Effect of Biodiesel Composition on Engine Emissions from a DDC Series 60 Diesel Engine: Final Report, Report 2 in a series of 6. National Renewable Energy Laboratory, Colorado Institute for Fuels and Engine Research, Colorado School of Mines, Golden Colorado, 2003.

Graham, L. A., Belisle, S. L., and Baas, C.-L.: Emissions from light duty gasoline vehicles operating on low blend ethanol gasoline and E85. Atmos. Environ., 42, 4498-4516, 2008.

Hasegawa, M., Sakurai, Y., Kobayashi, Y., Oyama, N., Sekimoto, M., and Watanabe, H.: Effects of Fuel Properties (Content of FAME or GTL) on Diesel Emissions under Various Driving Modes, SAE International, https://doi.org/10.4271/2007-014041, 2007.

Haskew, H. M. and Liberty, T. F.: Exhaust and Evaporative Emissions Testing of Flexible-Fuel Vehicles, Coordinating Research Council, Inc., 3650 Mansell Road Suite 140 Alpharetta, GA 30022, p. 473, 2011.

Hays, M. D., Preston, W., George, B. J., Schmid, J., Baldauf, R., Snow, R., Robinson, J. R., Long, T., and Faircloth, J.: Carbonaceous aerosols emitted from light-duty vehicles operating on gasoline and ethanol fuel blends, Environ. Sci. Technol., 47, 14502-14509, 2013.

Hixson, M., Mahmud, A., Hu, J. L., Bai, S., Niemeier, D. A., Handy, S. L., Gao, S. Y., Lund, J. R., Sullivan, D. C., and Kleeman, M. J.: Influence of regional development policies and clean technology adoption on future air pollution exposure, Atmos. Environ., 44, 552-562, 2010.

Hoek, G., Boogaard, H., Knol, A., de Hartog, J., Slottje, P., Ayres, J. G., Borm, P., Brunekreef, B., Donaldson, K., 
Forastiere, F., Holgate, S., Kreyling, W. G., Nemery, B., Pekkanen, J., Stone, V., Wichmann, H. E., and van der Sluijs, J.: Concentration Response Functions for Ultrafine Particles and AllCause Mortality and Hospital Admissions: Results of a European Expert Panel Elicitation, Environ. Sci. Technol., 44, 476482, 2010.

Jayaram, V., Agrawal, H., Welch, W. A., Miller, J. W., and Cocker III, D. R.: Real-time gaseous, PM and ultrafine particle emissions from a modern marine engine operating on biodiesel, Environ. Sci. Technol., 45, 2286-2292, 2011.

Johnston, J., Mileva, A., Nelson, J. H., and Kammen, D. M.: SWITCH-WECC. Data, Assumptions, and Model Formulation, Renewable and Appropriate Energy Laboratory, Berkeley, California, 2013.

Keshavarzmohammadian, A., Henze, D. K., and Milford, J. B.: Emission Impacts of Electric Vehicles in the US Transportation Sector Following Optimistic Cost and Efficiency Projections, Environ. Sci. Technol., 51, 6665-6673, 2017.

Knol, A. B., de Hartog, J. J., Boogaard, H., Slottje, P., van der Sluijs, J. P., Lebret, E., Cassee, F. R., Wardekker, J. A., Ayres, J. G., Borm, P. J., Brunekreef, B., Donaldson, K., Forastiere, F., Holgate, S. T., Kreyling, W. G., Nemery, B., Pekkanen, J., Stone, V., Wichmann, H. E., and Hoek, G.: Expert elicitation on ultrafine particles: likelihood of health effects and causal pathways, Part. Fibre Toxicol., 6, 19, https://doi.org/10.1186/1743-8977-6-19, 2009.

Kreyling, W. G., Semmler, M., and Moller, W.: Dosimetry and toxicology of ultrafine particles, J. Aerosol Med., 17, 140-152, 2004.

Lobo, P., Hagen, D. E., and Whitefield, P. D.: Comparison of PM emissions from a commercial jet engine burning conventional, biomass, and Fischer-Tropsch fuels, Environ. Sci. Technol., 45, 10744-10749, 2011.

Lobo, P., Rye, L., Williams, P. I., Christie, S., Uryga-Bugajska, I., Wilson, C. W., Hagen, D. E., Whitefield, P. D., Blakey, S., Coe, H., Raper, D., and Pourkashanian, M.: Impact of alternative fuels on emissions characteristics of a gas turbine engine part 1: gaseous and particulate matter emissions, Environ. Sci. Technol., 46, 10805-10811, 2012.

Loughlin, D. H., Benjey, W. G., and Nolte, C. G.: ESP v1.0: methodology for exploring emission impacts of future scenarios in the United States, Geosci. Model Dev., 4, 287-297, https://doi.org/10.5194/gmd-4-287-2011, 2011.

Loulou, R., Goldstein, G., Kanudia, A., Lettila, A., and Remme, U.: Documentation for the TIMES Model. Part I: Times Concepts and Theory, in: (IEA-ETSAP), I.E.A.-E.T.S.A.P. (Ed.), Energy Technology Systems Analysis Programme, available at: http://www.iea-etsap.org/web/Documentation.asp (last access: September 2017), 2016.

Lundqvist, R. G.: The IGCC demonstration plant at Värnamo, Bioresource Technol., 46, 49-53, 1993.

Mann, M. K. and Spath, P. L.: Life Cycle Assessment of a Biomass Gasifiction Combined-Cycle System. National Renewable Energy Laboratory, National Renewable Energy Laboratory, 15013 Denver West Parkway, Golden, CO 80401, 303-275-3000, 1997.

McCollum, D., Yang, C., Yeh, S., and Ogden, J.: Deep greenhouse gas reduction scenarios for California - Strategic implications from the CA-TIMES energy-economic systems model, Energy Strateg. Rev., 1, 19-32, 2012.
Nelson, D. J., Mileva, A., Johnston, J., and Kammen, P. D.: Scenarios for Deep Carbon Emission Reductions from Electricity by 2050 in Western North America Using the SWITCH Power Electric Power Sector Planning Model. California's Carbon Challenge Phase II, in: California Energy Commission (Ed.). Renewable and Appropriate Energy Laboratory Energy and Resources Group, 310 Barrows Hall Berkeley, CA 94720-3050, University of California, Berkeley, p. 142, 2013.

Oberdorster, G., Sharp, Z., Atudorei, V., Elder, A., Gelein, R., Lunts, A., Kreyling, W., and Cox, C.: Extrapulmonary translocation of ultrafine carbon particles following whole-body inhalation exposure of rats, J. Toxicol. Env. Heal. A, 65, 1531-1543, 2002.

Osborne, D., Fritz, S., and Glenn, D.: The Effects of Biodiesel Fuel Blends on Exhaust Emissions from a General Electric Tier 2 Line-Haul Locomotive, ASME 2010 Internal Combustion Engine Division Fall Technical Conference. ASME, San Antonio, Texas, USA, 2010.

Ostro, B., Hu, J., Goldberg, D., Reynolds, P., Hertz, A., Bernstein, L., and Kleeman, M. J.: Associations of mortality with long-term exposures to fine and ultrafine particles, species and sources: results from the California Teachers Study Cohort, Environ. Health Persp., 123, 549-556, 2015.

Parker, N.: Spatially Explicit Projection of Biofuel Supply for Meeting Renewable Fuel Standard, Transport Res. Rec.: J. Transport Res. Board, 2287, 72-79, 2012.

Petzold, A., Lauer, P., Fritsche, U., Hasselbach, J., Lichtenstern, M., Schlager, H., and Fleischer, F.: Operation of marine diesel engines on biogenic fuels: modification of emissions and resulting climate effects, Environ. Sci. Technol., 45, 10394-10400, 2011.

Rafaj, P., Schöpp, W., Russ, P., Heyes, C., and Amann, M.: Cobenefits of post-2012 global climate mitigation policies, Mitig. Adapt. Strat. Gl., 18, 801-824, 2012.

Ran, L., Loughlin, D. H., Yang, D., Adelman, Z., Baek, B. H., and Nolte, C. G.: ESP v2.0: enhanced method for exploring emission impacts of future scenarios in the United States - addressing spatial allocation, Geosci. Model Dev., 8, 1775-1787, https://doi.org/10.5194/gmd-8-1775-2015, 2015.

Rounce, P., Tsolakis, A., and York, A. P. E.: Speciation of particulate matter and hydrocarbon emissions from biodiesel combustion and its reduction by aftertreatment, Fuel, 96, 90-99, 2012.

Rudokas, J., Miller, P. J., Trail, M. A., and Russell, A. G.: Regional air quality management aspects of climate change: impact of climate mitigation options on regional air emissions, Environ. Sci. Technol., 49, 5170-5177, 2015.

Shindell, D., Kuylenstierna, J. C. I., Vignati, E., van Dingenen, R., Amann, M., Klimont, Z., Anenberg, S. C., Muller, N., JanssensMaenhout, G., Raes, F., Schwartz, J., Faluvegi, G., Pozzoli, L., Kupiainen, K., Höglund-Isaksson, L., Emberson, L., Streets, D., Ramanathan, V., Hicks, K., Oanh, N. T. K., Milly, G., Williams, M., Demkine, V., and Fowler, D.: Simultaneously Mitigating Near-Term Climate Change and Improving Human Health and Food Security, Science, 335, 183, 2012.

Ståhl, K. and Neergaard, M.: IGCC power plant for biomass utilisation, Värnamo, Sweden, Biomass Bioenerg., 15, 205-211, 1998.

Starcrest Consulting Group, L.: San Pedro Bay Ports Clean Air Action Plan: 2010 Update. Appendix A: San Pedro Bay Ports Emissions Forecasting Methodology \& Results. The Port of Los 
Angeles, The Port of Long Beach, P. O. Box 434, Poulsbo, WA 98370, 2009.

State of California, D.o. F.: Report P-1 (County): State and County Total Population Projections, 2010-2060, Sacramento, California, 2013.

Szybist, J. P., Youngquist, A. D., Barone, T. L., Storey, J. M., Moore, W. R., Foster, M., and Confer, K.: Ethanol Blends and Engine Operating Strategy Effects on Light-Duty Spark-Ignition Engine Particle Emissions, Energ. Fuel., 25, 4977-4985, 2011.

The Port of Los Angeles, The Port of Long Beach: San Pedro Bay Ports Clean Air Action Plan: 2010 Update, The Port of Los Angeles, Los Angeles, CA, USA, 2010.

Tittmann, P. W., Parker, N. C., Hart, Q. J., and Jenkins, B. M.: A spatially explicit techno-economic model of bioenergy and biofuels production in California, J. Transp. Geogr., 18, 715-728, 2010.

Trail, M. A., Tsimpidi, A. P., Liu, P., Tsigaridis, K., Hu, Y., Rudokas, J. R., Miller, P. J., Nenes, A., and Russell, A. G.: Impacts of potential $\mathrm{CO} 2$-reduction policies on air quality in the United States, Environ. Sci. Technol., 49, 5133-5141, 2015.

Tsujimura, T., Goto, S., and Matsubara, H., "A Study of PM Emission Characteristics of Diesel Vehicle Fueled with GTL", SAE Technical Paper 2007-01-0028, https://doi.org/10.4271/2007-010028, 2007.

US Department of Agriculture Rural Development Agency: Cooperative Approaches for Implementation of Dairy Manure Digesters, in: Agency, R. D. (Ed.), STOP 3252, 1400 Independence Ave., S.W, Washington, DC 20250-3252, 2009.

US Department of Energy National Energy Technology Laboratory: Archived 2010 Worldwide Gasification Database, available at: www.netl.doe.gov/research/coal/energy-systems/ gasification/gasification-plant-databases/2010-archive (last access: June 2015), 2010.

US Department of Energy National Energy Technology Laboratory: United States Proposed Gasification Plant Database, March 2015. ed. US Department of Energy, National Energy Technology Laboratory, available at: www.netl.doe.gov/ File\%20Library/Research/Coal/energy\%20systems/gasification/ worldwide\%20database/US-Gasification-Database.xlsx, last access: June, 2015.

US Energy Information Administration Independent Statistics and Analysis: Electricity. Form EIA-860 detailed data, available at: www.eia.gov/electricity/data/eia860/ (last access: February 2014), 2012.

US Environmental Protection Agency AgSTAR Program: Market Opportunities for Biogas Recovery Systems at US Livestock Facilities, in: US Environmental Protection Agency (Ed.), US Environmental Protection Agency, Washington DC, USA, 2011.
US Environmental Protection Agency: eGRID. Nineth edition with year 2010 data (Version 1.0), 9th ed. Environmental Protection Agency, p. The Emissions \& Generation Resource Integrated Database (eGRID) is a comprehensive source of data on the environmental characteristics of almost all electric power generated in the United States, US Environmental Protection Agency, Washington DC, USA, 2014.

van Aardenne, J., Dentener, F., Van Dingenen, R., Maenhout, G., Marmer, E., Vignati, E., Russ, P., Szabo, L., and Raes, F.: Climate and air quality impacts of combined climate change and air pollution policy scenarios., JRC Scientific and Technical Reports. European Commission. Joint Research Centre. Institute for Environment and Sustainability, Luxembourg: Publications Office of the European Union, 2010.

West, J. J., Smith, S. J., Silva, R. A., Naik, V., Zhang, Y., Adelman, Z., Fry, M. M., Anenberg, S., Horowitz, L. W., and Lamarque, J. F.: Co-benefits of Global Greenhouse Gas Mitigation for Future Air Quality and Human Health, Nat. Clim. Change, 3, 885-889, 2013.

Yang, C., Yeh, S., Ramea, K., Zakerinia, S., McCollum, D., Bunch, D., and Ogden, J.: Modeling Optimal Transition Pathways to a Low Carbon Economy in California: California TIMES (CA-TIMES) Model, Institute of Transportation Studies, University of California, Davis, CA, 2014.

Yang, C., Yeh, S., Zakerinia, S., Ramea, K., and McCollum, D.: Achieving California's $80 \%$ greenhouse gas reduction target in 2050: Technology, policy and scenario analysis using CATIMES energy economic systems model, Energ. Policy, 77, 118130, 2015.

Yoon, S., Hu, S., Kado, N. Y., Thiruvengadam, A., Collins, J. F., Gautam, M., Herner, J. D., and Ayala, A.: Chemical and toxicological properties of emissions from CNG transit buses equipped with three-way catalysts compared to lean-burn engines and oxidation catalyst technologies, Atmos. Environ., 83, 220-228, 2014.

Zhang, H., Chen, G., Hu, J., Chen, S. H., Wiedinmyer, C., Kleeman, M., and Ying, Q.: Evaluation of a seven-year air quality simulation using the Weather Research and Forecasting (WRF)/Community Multiscale Air Quality (CMAQ) models in the eastern United States, Sci. Total Environ., 473-474, 275-285, 2014.

Zhang, Y., Bowden, J. H., Adelman, Z., Naik, V., Horowitz, L. W., Smith, S. J., and West, J. J.: Co-benefits of global and regional greenhouse gas mitigation for US air quality in 2050, Atmos. Chem. Phys., 16, 9533-9548, https://doi.org/10.5194/acp16-9533-2016, 2016. 